\title{
من أعلام الأزهر
}

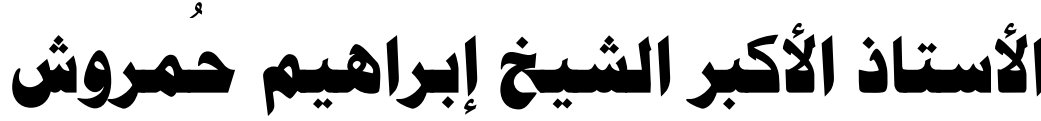

شيخ الجاهع الأزهر السابق

عضو هيئة كبار العلماء

p197./11/10-114./T/1

للاكتور علي إبراهييم همهد

أستاذ علم اللغة بجامعتني الأزهر وأم القرى 


\section{من أعلام الأزهر الأستاذ الأكبر الشيخ / إبراهيم حُمروش علي إبراهيم محمد)}

علي إبر اهيم محمد

أستاذ أصول اللغة بجامعتي الأزهر وأم القرى. البريد الإليكتروني: aemohammad@uqu.edu.sa

\section{مط:م البمث}

يهدف هذا البحث الكشف عن جوانب من حياة الأستاذ الثيخ حُمروش

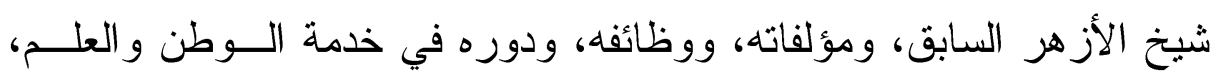
وقد التزمنا المنهج الوصفي الذي توصلنا من خلاله إلى مجموعة من ومن النتـائج

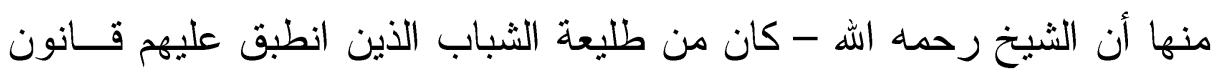

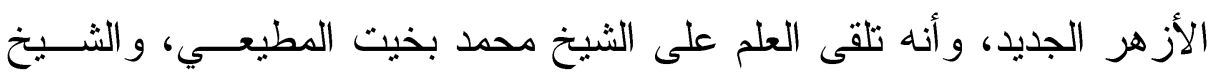
أحمد أبي خطوة، والإمام محمد عبده، وأن أشهر تلاميذه الثيخ حسن مــأمون

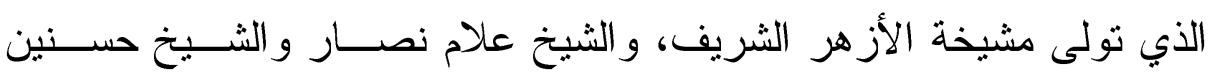

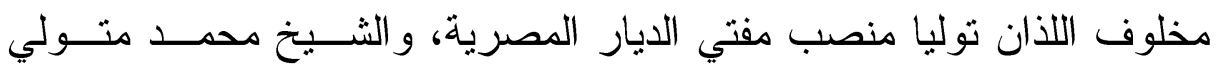

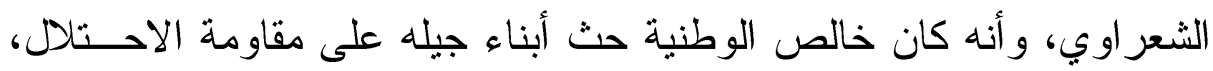
ولمكانته التحق بمجمع اللغة العربية وهيئة كبار العلماء في عامين متتـاليين، وجملة ما كتب ستة مؤلفات. الكلمات المفتاحية: [حمروش - إبر اهيم - شيخ - الأزهر - كبار العلماء]. 


\section{One of Al-Azhar Luminaries}

The Grand Master Sheikh Ibrahim Homroush

The late Grand Imam of al-Azhar

Member of the Council of Senior Scholars

1/3/1880 AD - 15/11/1960

\section{Ali Ibrahim Mohamed}

Professor of Origins of Language at Al-Azhar and Umm AlQura universities.

Email: aemohammad@uqu.edu.sa

\section{Abstract}

This research aims to detect the aspects of the life of Professor Sheikh Homroush, the late Sheikh of Al-Azhar, his writings, jobs, and his role in serving the nation and science. The descriptive approach has been followed and through which a set of results have been reached including the fact that the Sheikh, may God have mercy on him, was among the forefront of young people to which the new Al-Azhar law was applied. Another result is that he received education from Sheikh Mohamed Bakhit Al-Mutai, Sheikh Ahmed Abo Khatwa, and Imam Mohamed Abdo, in addition to his most famous student Sheikh Hassan Ma'moun, who headed the honorable Sheikhdom Azhar, Sheikh Allam Nassar and Sheikh Hassanein Makhlouf, who assumed the position of Mufti of Egypt, and Sheikh Mohamed Metwali Al-Shaarawi. Sheikh Homroush was truly a patriot urging the people of his generation to resist the occupation. For his stature, he joined the Arabic Language Academy and the Council of Senior Scholars in two consecutive years. Moreover, he authored a total of six publications during his life.

Key words: [Homroush - Ibrahim - Sheikh - Al-Azhar Senior Scholars] 
الحمد لله رب العالمين، و العاقبة للمتقين، و الصـلاة و الســـلام الأتمــان على خير خلق الله - تعالى - أجمعين سيدنا محمد النبي الأمي الكريم، وعلى ولى وله وله آله وصحبه ومن سار على هديه و اقتفى أثره إلى يوم الدين، وبعدئ...

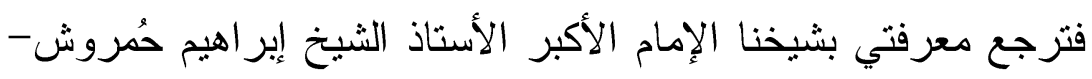

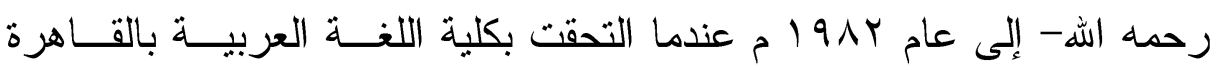
جامعة الأزهر حين دخلت الكلية لأول مرة لطلب التحويل إليها من كلية اللغة

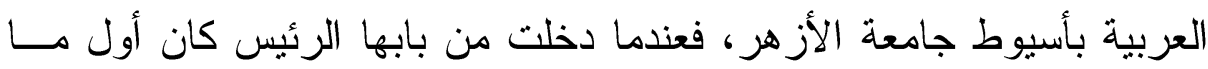

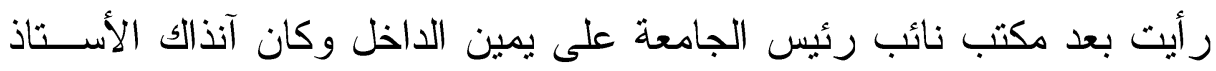
الدكتور العارف باله - تعالى - الأستاذ الدكتور عبد الرحمن الكردي- رحمه رلهئ الله- ، ومكتب عميد الكلية، كان أول ما رأيت بعد هذين المكتبين مدرج الكلية

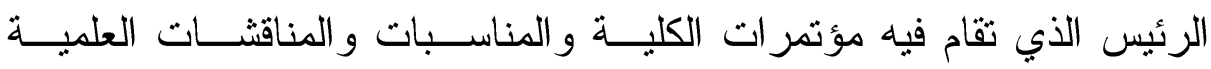
المعروف باسم مدرج الثيخ حُمروش، وقد اطلق على هذا المدرج اسم الثيخ - رحمه الهـ- تخليدًا له وكيف لا و هو أول عميد لهذه الكلية المباركة، و أكثــر

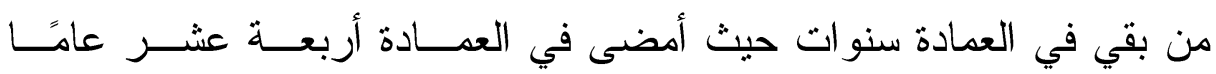
. (م) $9 \leq \leq-1941)$

و عندما علمت بمؤتمر كلية الدراسات الإسلامية والعربية للبنات ببني سويف جامعة الأزهر الذي يحمل عنوان: "دور الأزهر الثريف في الحفــاظ

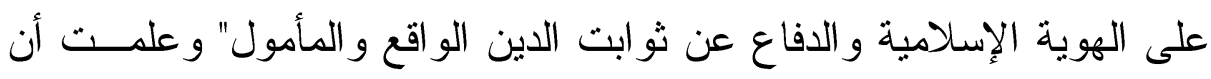

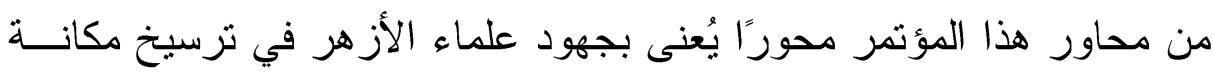

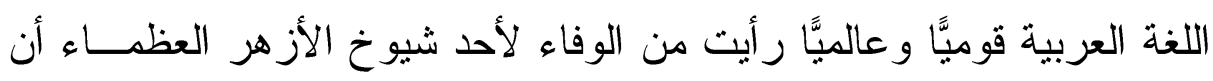

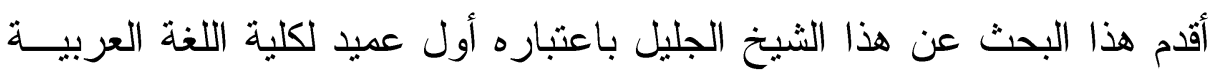

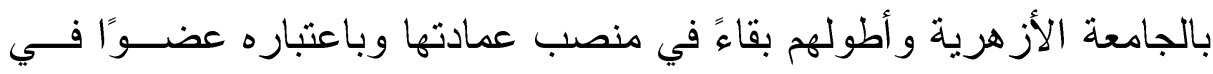

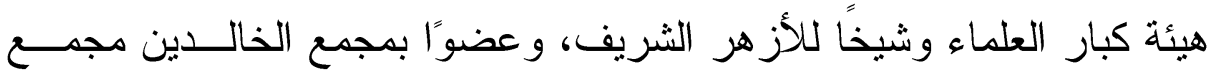

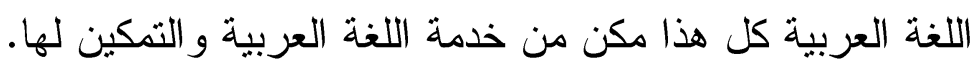


وكان هذا البحث قد قبل للمشاركة في هذا المؤتمر غيــر أن جائحـــة كورونا أجلت هذا المؤتمر لأجل غبر مسمى لذلك رأيت نشره في مجلة الكلية التي تعد للمؤتمر كلية الدر اسات الإسلامية و العربية للبنات بيني سويف جامعة

وقد اقتضت طبيعة هذا البحث أن يكون في شكل النقاط الآتية:

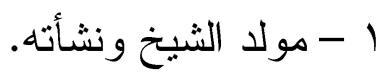

$$
\text { r - شيوخه. }
$$

ع - الثيخ في هيئة كبار العلماء.

0 - الشيخ في مجمع اللغة العربية.

7

- V

^ - من مو اقفه الحماسية في الحث على الجهاد والذود عن الوطن.

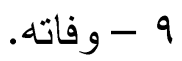

ثم في النهاية قائمة بأهم المصادر و المر اجع المستخدمة في البحث. و إذا كان من سمات البحث العلمي الجاد الإشارة إلى الأعمال السابقة فإنني أثير هنا إلى أهم من كتب عن الثيخ ممن سبقني على النحــو الآتي:

الأستاذ الأكبر الشيخ إبر اهيم حمروش مقال للأستاذ محمد علي النجار

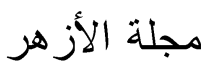




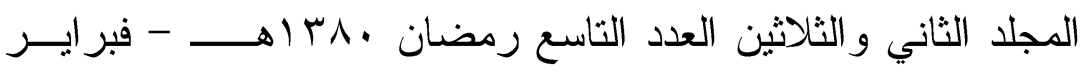

ا آو (م، وهذا المقال

كلمة ألقاها الشيخ النجار في مناسبة تأبين الأســتاذ الأكبـر الثــيخ

$$
\text { حمروش في مجمع }
$$

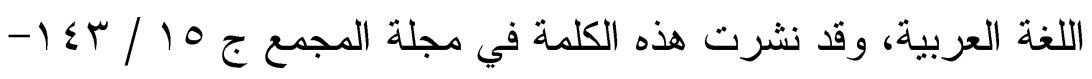

$$
\text { . } 10 \text { : بعنوان: }
$$

" المرحوم فضيلة الثيخ إبر اهيم حمروش".

الأزهر في ألف عام د محمد عبد المنعم خفاجي، ود علي علي صبح

$$
\text { brی/r ج }
$$

ب المكتبة الأزهرية للتر اث 9 ه . . بم.

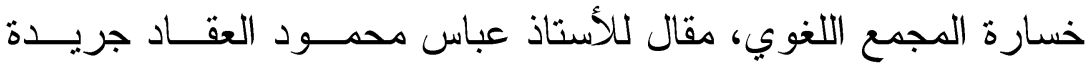

الأخبار

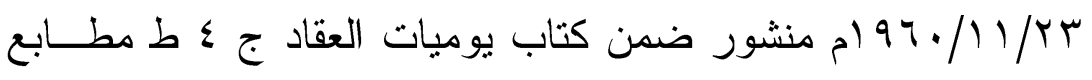

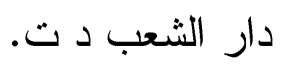

وإني إذ أقدم هذا البحث الموجز عن الشيخ لا أزعم أنني وفيته حقه ولكن هي صفحات تثناسب والمقام الذي قُدمت فيه ولعلها تلقى أثرًا لدى أحد الباحثين في الدراسات العليا فيسجل فيه رسالة علمية تبرز جهــود الشــيخ للدارسين.

و الله أسأل لمو لانا الإمام الأكبر الأســتاذ الثـــيخ بـــر اهيم حُـــروش

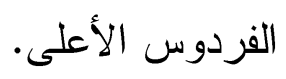

ا مولد الشيخ ونشأته

ولد شيخنا في قرية الخو الد التابعة لمركز إيتابي البارود مــن أعمــال 


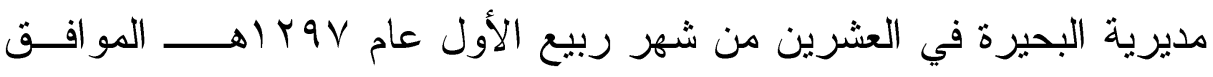

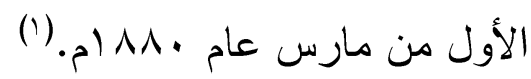
نشأ في قريته التي ولا فيها و التحق بكتاب القرية فحفظ القرآن الكريم كاملا في الثانية عشرة من عمره أرسله و الده إلى الأزهر الثريف فالتحق به، وله وله وكان الثيخ - رحمه الله - حينئذ من طليعة الشباب الذين تم تطبيق القـانون

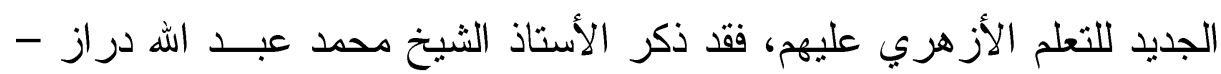
رحمه الله - صدور قانون الجامع الأزهر الجديد في العشرين من المحرم سنة الأنادي

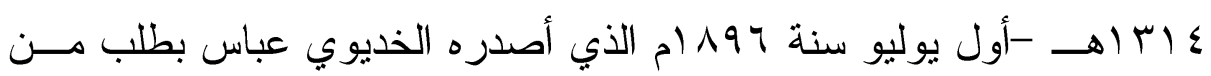
الشيخ محمد عبده - رحمه الله- ، وقد جاء في هذا القانون أن بعض العلــوم الرياضية كالحساب و الجبر تعد مو اد إجبارية ( مادة V V) ، وبعــ وله العلــوم كالهندسة والجغر افيا و التاريخ تعد اختيارية، ويكون بها الترجيح ولئ والإيثار (مادة

(r). $(1 \wedge$

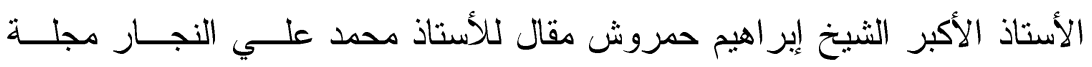

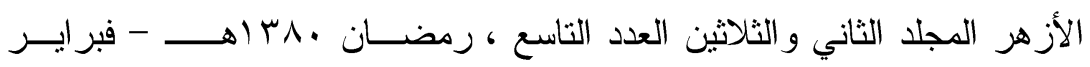

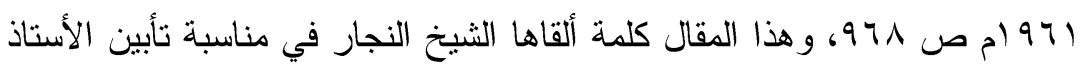

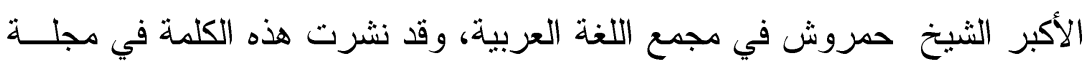

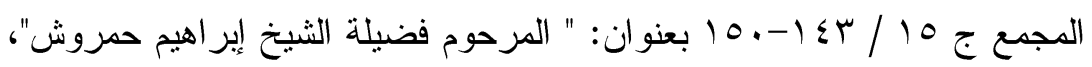

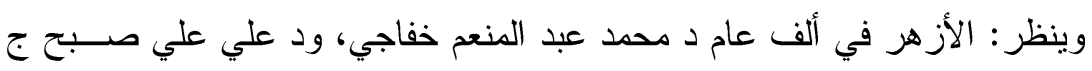

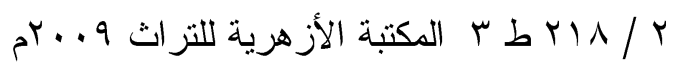

الأزهر الجامعة القديمة - الحديثة، مقال للأستاذ الثيخ محمد عبد الله دراز مجلة

$$
\text { الأزهر مج بr العدد الخامس الجعة الفايمة }
$$

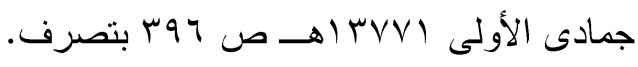




\section{r - شيوخه}

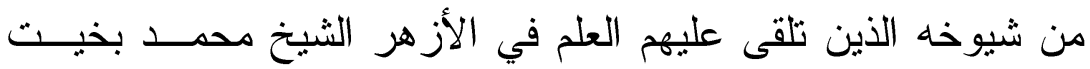

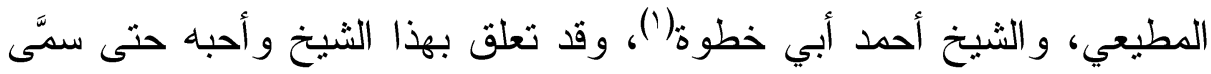

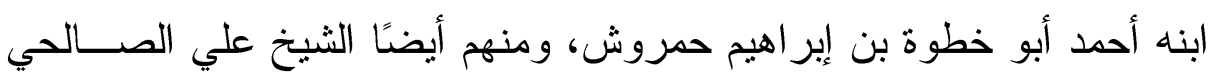

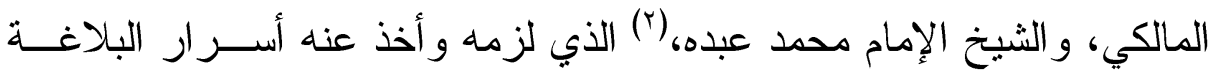

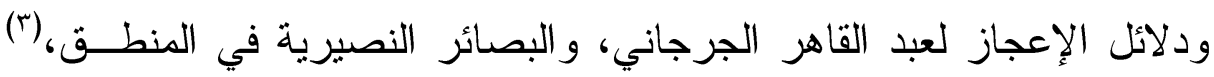

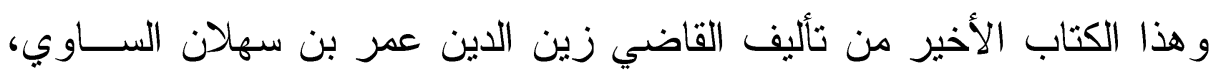

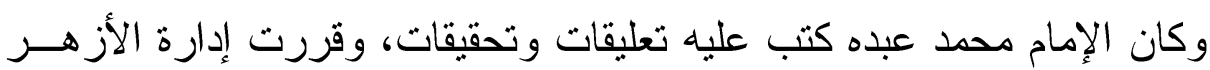

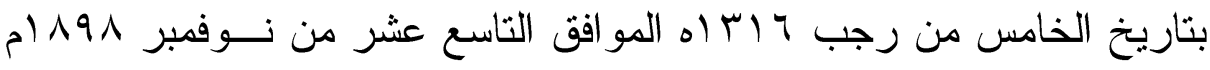

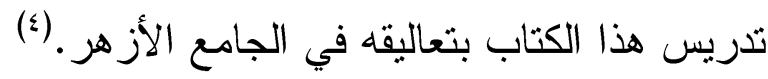
وظل الثيخ يطلب العلم حتى سنة 19 19 م حيث تقدم لاختبار العالمية وكان صغير السن بين أقرانه، وكان الاختبار في أربعة عشر علمًا يقضي فيه

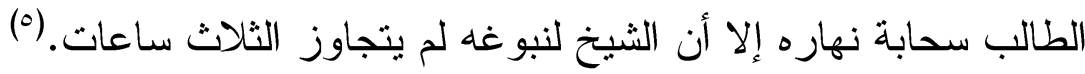

موسوعة أعلام الفكر الإسلامي - وزارة الأوقاف المصرية ص اب ط المجلـس

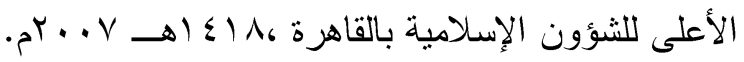

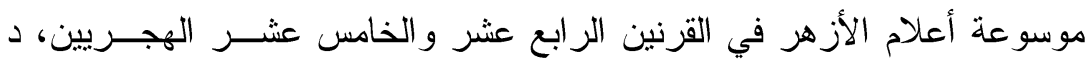

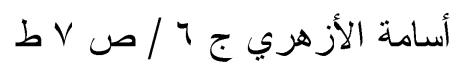

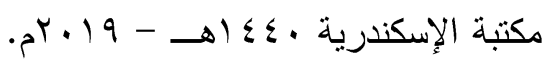

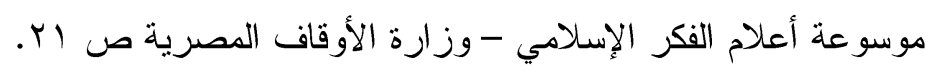

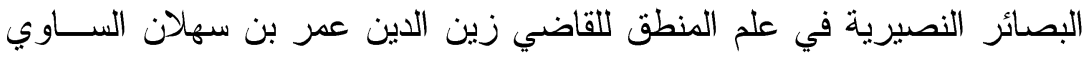

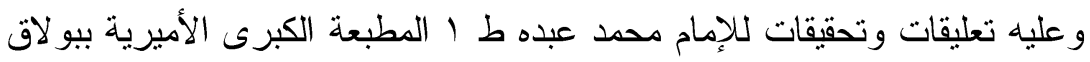

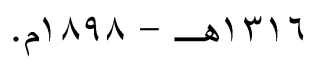

الأستاذ الأكبر الثيخ إبر اهيم حمروش، مقال للأستاذ محمد على النجار ص 979.

$$
-11 \leq 1-
$$


ومن طر ائف الاختبار التي حصلت مع الثيخ ما ذكره الأستاذ الثــيخ محمد علي النجار - رحمه الله - من أن "امتحان العالمية في أصول الفقه كان

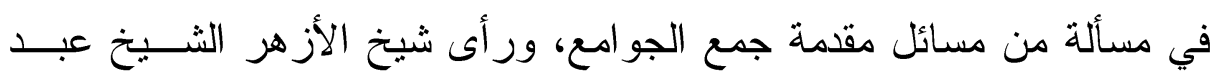

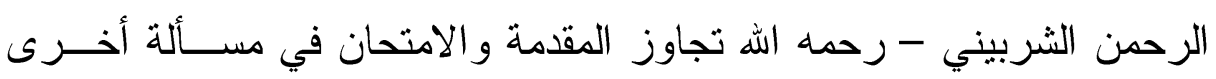
حتى لا يقصر الطلاب جهودهم على المقدمة، فعين مسألة للامتحان في القياس فتخلف كثير ممن جاء مو عد امتحانهم، فأُبيح التقدم لمن بعدهم فتقدم الثيخ ففاز

$$
\begin{aligned}
& \text { في امتحان دقيق". (') } \\
& \text { ب - تلاميذه }
\end{aligned}
$$

من أنجب تلاميذه الذين انتشر ذكرهم وعم النفع بعلمهم فضيلة الشيخ

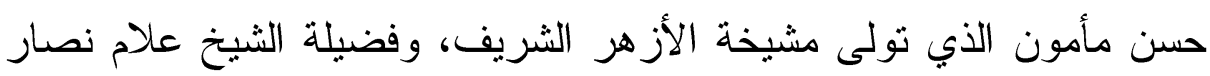
وفضيلة الثيخ حسنين مخلوف اللذان توليا منصب مفتي الــديار المصــرية،

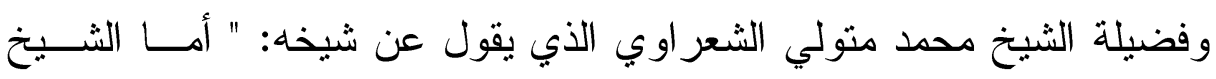

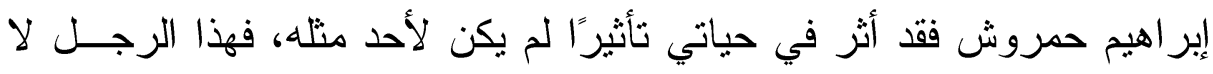

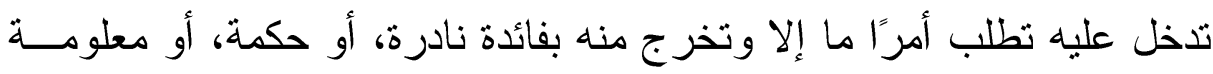

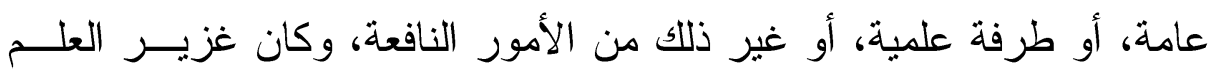

$$
\text { باللغة و غير ها". (r) }
$$

كما كان من أنجب تلاميذه فضيلة الثيخ فرج السنهوري - رحمه الله

- الذي كان من أعلام الفقه في مصر.

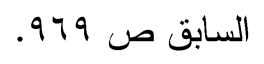

موسوعة أعلام الأزهر في القرنين الرابع عشر و الخامس عشر الهجريين د أسامة

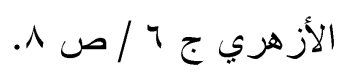

أئمة في سطور الثيخ إبر اهيم حمــروش، بوابـــة جريــدة الأهــرام المصــرية

$$
\text { . } r \cdot 11 / 0 / 47
$$


ع - الثيخ في مجمع اللغة العربية

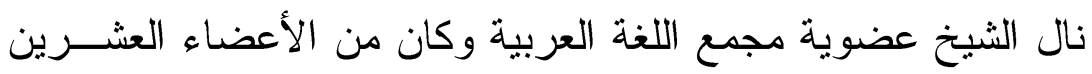

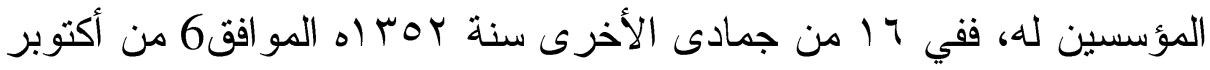

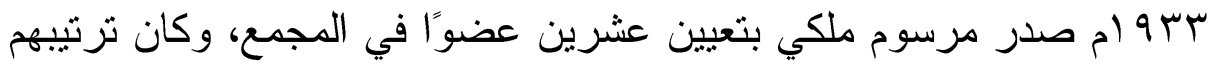

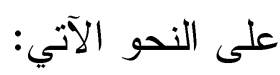

محمد توفيق رفعت بالاشا.

حايم نحوم أفندي.

الثيخ حسين و الي.

الدكتور فارس نمر .

الدكتور منصور فهمي.

الثيخ إبر اهيم حُمروش.

الشيخ محمد الخضر حسين.

أحمد العو امري بك.

علي الجارم أفندي.

الشيخ أحمد علي الإسكندري.

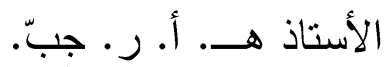

الأستاذ الدكتور أ. فيشر .

الأستاذ. م. ماسينيون.

الأستاذ أ. ج. فنسنك. مالك.

محمد كرد علي بك.

الأستاذ عبد القادر المغربي.

الأب أنستاس ماري الكِرِلي.

عيسى إسكندر المعلوف أفندي.

السيد حسن عبد الو هاب أفندي.(1)

مجلة مجمع اللغة العربية ج ا ص r ا ط المطبعة الأميرية ببولاق هبو ام. 
وفي أول تشكيل للجان المجمع ظهر اسم الثيخ في اللجان الآتية:

$$
\text { 1- الجنة الآداب و الفنون. }
$$

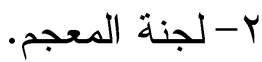

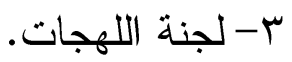

ع- لجنة الأصول العامة. (1)

وظل الشيخ في المجمع حتى وفاته سنة . 197 وحل محله في المجمع

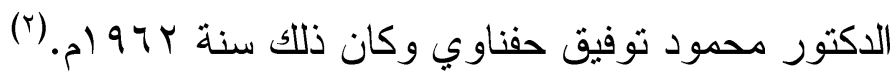

$$
\text { 0 - الثيخ في جماعة كبار العلماء }
$$

تُوجت حياة الشيخ العلمية بدخوله في جماعة كبار العلماء في الثـامن و العشرين من صفر سنة سهب اهـ - الموافق العاشر من يونية سنة عبو ام، وقد قدم لنيل هذه الدرجة رسالة جليلة تحمل عنوان:" عو امل نمو اللغة" يقــول هول في مقدمتها:" وبعد.. فاللغة العربية بفضل و املها المتعـددة رحــب صــدر ها

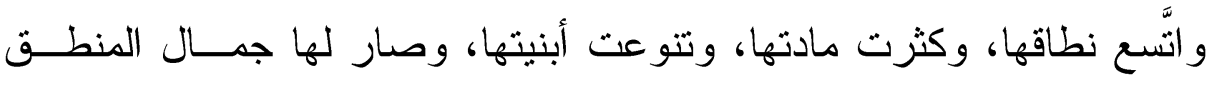

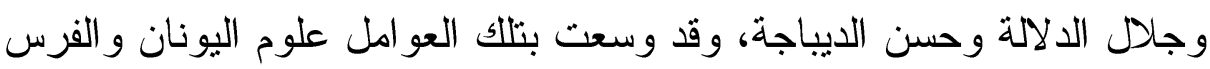

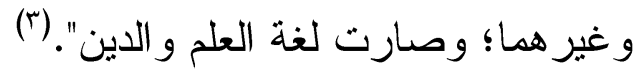

" وقد كتبت كلمة في التوليد بالزيادة و الإبــدال و القاــبـ و الاثـــقاق

و التر ادف و الاشتر الك و المجاز و النحت و الارتجال و التعريب".

$$
\text { مجلة المجمع ج / / ابr - سr. }
$$

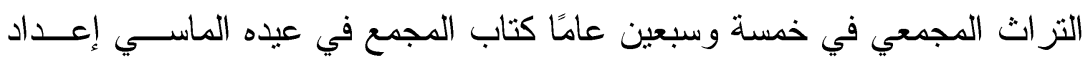

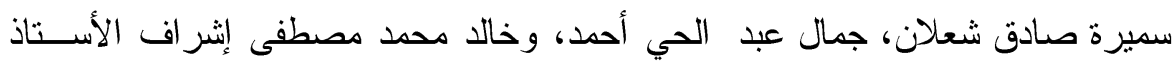

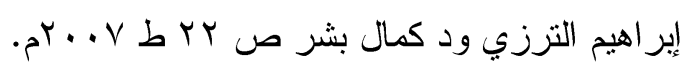

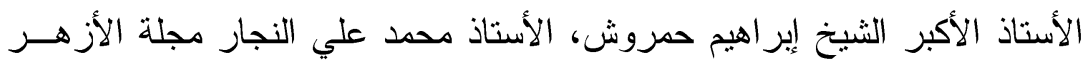

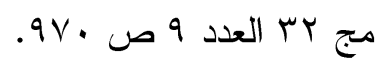


وكان له - من خلال هذا المؤلف - موقف من التعريب ذكره بعد أن

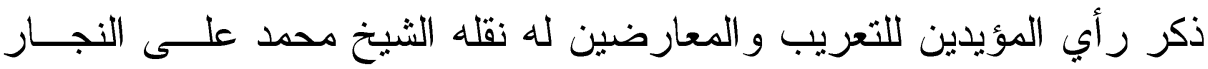

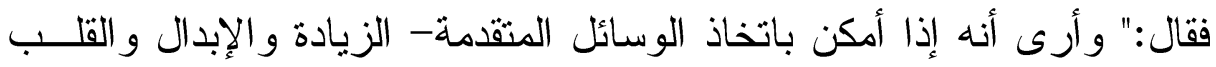

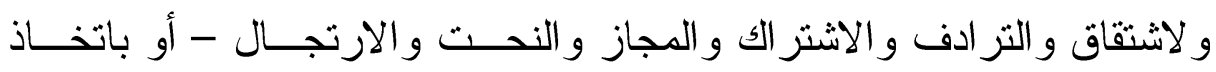

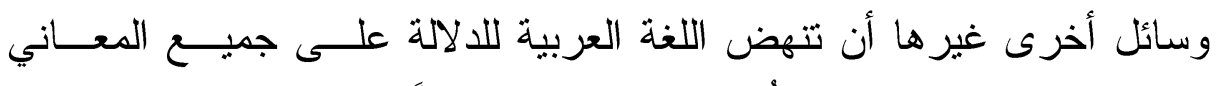

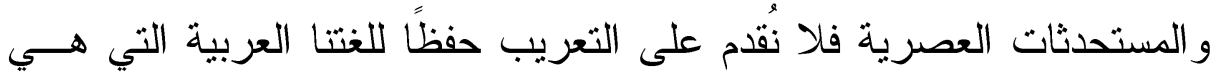
أداة فهم القرآن والحديث اللذين هما أساس الدين و عماده. و إن لم يمكن أن تقوم

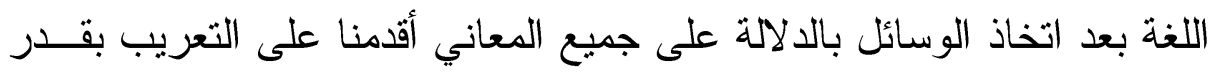
الحاجة فقط، مع المحافظة على اللغة الفصحى، بأن نذكر اللفظ ونذكر بجانبه

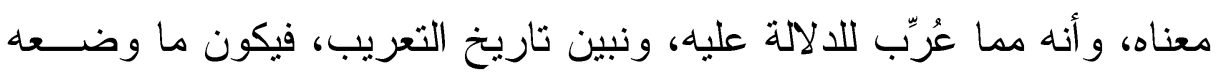
المتقدمون معروفًا، وما أُلحق باللغة معروفًا، فتحقق المحافظة على على الموروثاث عن السلف". (') ولهذا الموقف من المعرب وصفه د محمد رشاد الحمزاوي بأنه: " كان

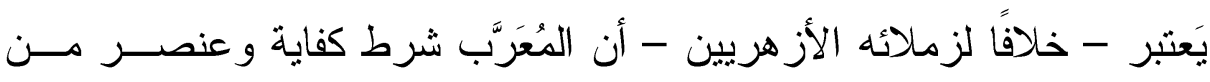
عناصر تتمبة اللغة العربية". (؟) و ون مو اقفه المرنة في التعامل مع الثواهد قال الأستاذ عباس العقــاد

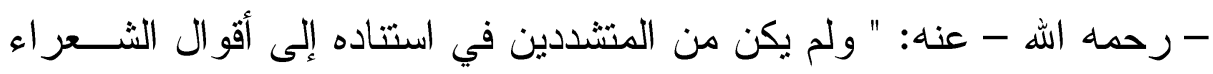

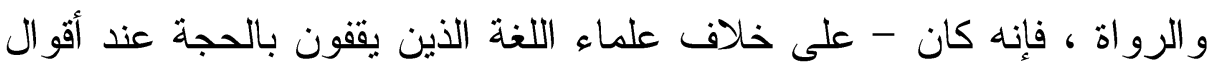

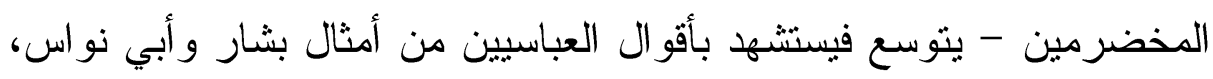

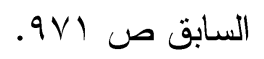

أعمال مجمع اللغة العربية بالقاهرة د محمد رشاد الحمـز اوي ص مي ط ا دار

$$
\text { الغرب الإسلامي بيروت } 911 \text { ام. }
$$


بل يستشهد أحيانًا بأقو ال المولدين المتأخرين إذا درجت في مدارج الاستعمال

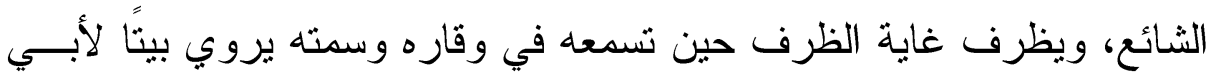
نواس أو لبشار لا يتحرج في هذا ولا ذاك، و لا يبالي الثيخ لغوهـ هما إذا كــان

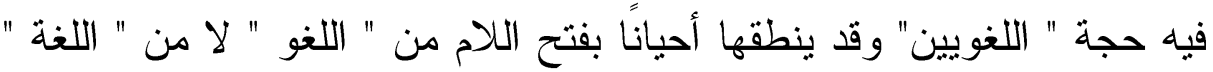
تفكهًا منه على حسب المقام". (1) T - آثاره العلمية أ - التضمين ونيابة بعض الحروف عن بعض التره بحث منشور في محاضر جلسات دور الانعقاد الأول لمجمــع اللغـــة بعنة العربية بالقاهرة، يقع في خمس صفحات. وهو عبارة عن نصوص نقلها الثيخ من حاشية الخضري على ابــن عقيل، وحاشية الصبَّان على الأشموني، وتقرير الأنبابي على حاشية الأمبـر ، ونصين من مغني اللبيب لابن هشام أحدهما من الجزء الأول، و النص الثـاني

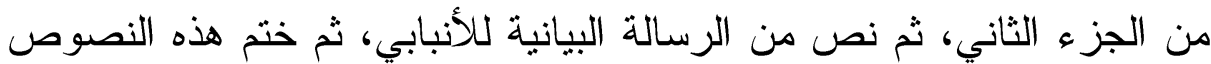

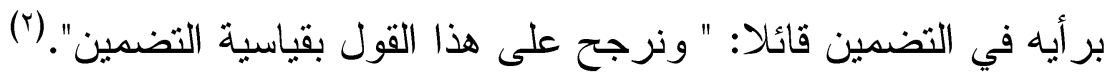
وكان التضمين ونيابة بعض الحروف عن بعض من الأمــور التـي فئي

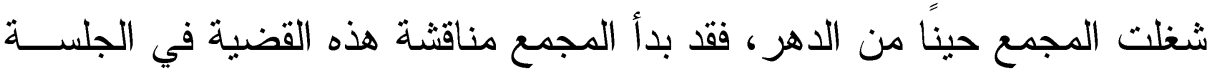

خسارة المجمع اللغوي، مقال للأستاذ عباس محمــود العقــاد جريــدة الأخبـار

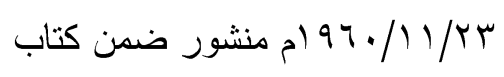

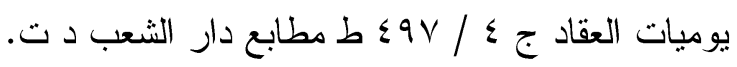

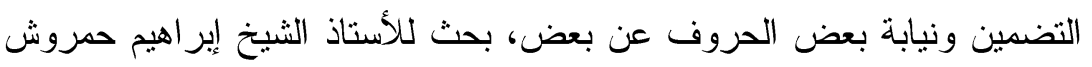

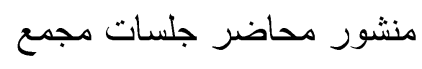

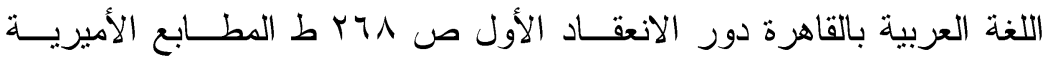


السادسة عشرة، وفيها قدم الأستاذ الشيخ حسين و الي - رحمه الله- بحثًا بعنوان

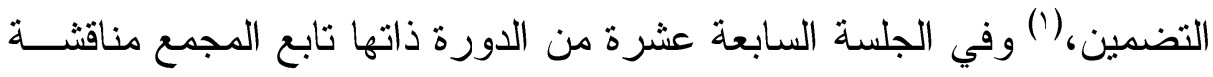

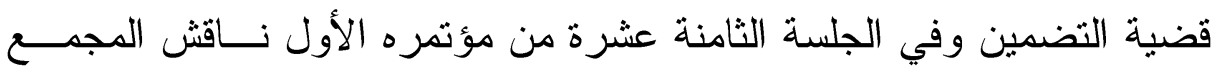
قضية نيابة بعض الحروف عن بعض، (r) وفي الجلسة ذاتها قدم الأستاذ الشيخ محمد الخضر حسين بـن - رحمه الله

- بحثًا في نيابة بعض الحروف عن بعض.(r)

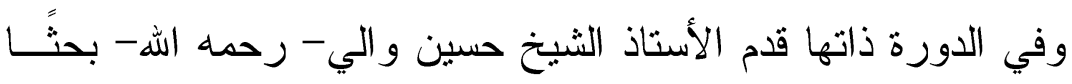
بعنوان:" هل ينوب بعض حروف الجر عن بعض" وهو بحث مفصل جاء في

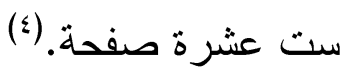
= الرد على بحث الثيخ محمد الطاهر بن عاشور " فرق لغوي مغفول

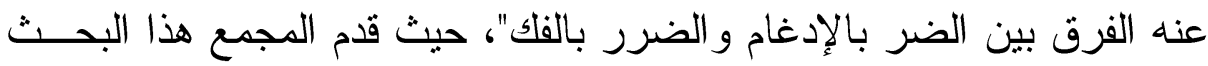

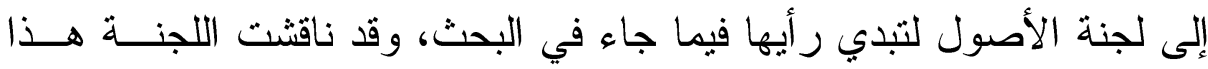

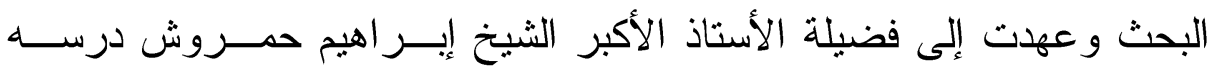
وبحثه، فقدم نتيجة در استه لهذا البحث و هذا نصها:

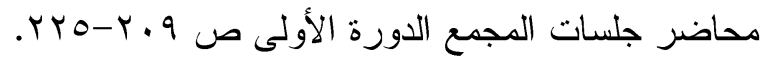

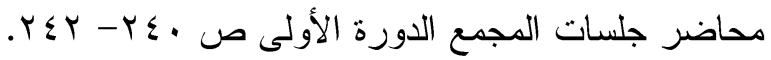

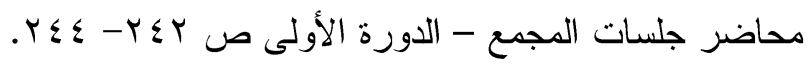

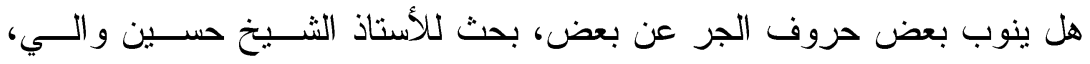

$$
\begin{aligned}
& \text { محاضر جلسات مجمع اللغة العربية }
\end{aligned}
$$

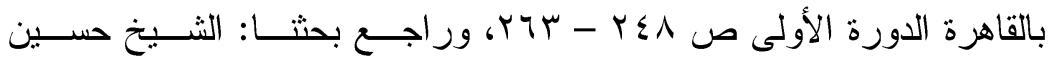

$$
\begin{aligned}
& \text { و الي اللغوي المغور ، بحث منشور في بالهرة }
\end{aligned}
$$

مجلة كلية اللغة العربية بالقاهزة جامعة الأزهر العــد الســادس و العشـرين 
" قال علماء الصرف: إن العرب تلاعبو ابمصادر الأفعــال الثلاثيــة

$$
\text { تلاعبًا كثيرًا. }
$$

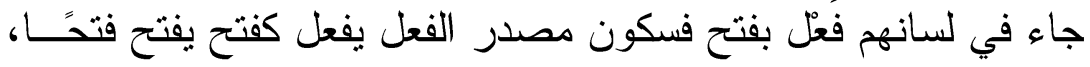

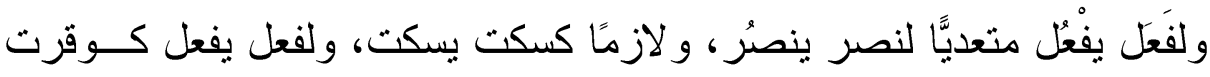

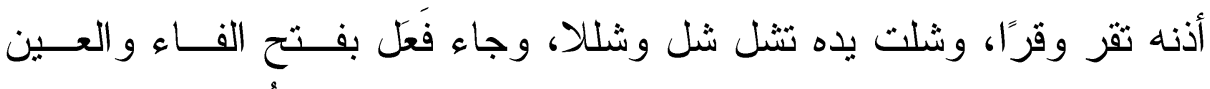

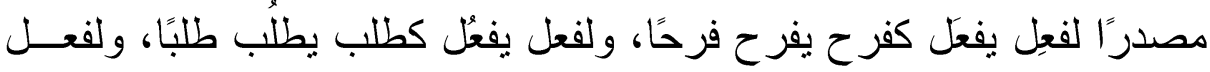

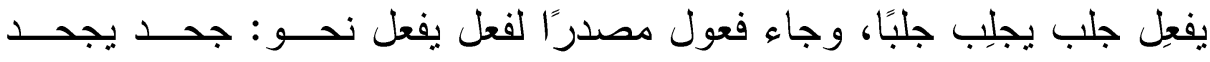
جحودًا ولفعل يفعل سكت يسكت سكوتا، ولفعل يفحِل نحو ورد المــاء ورودًا إلى غير ذلك.

فإذا ورد مصدر على وزن فَعَل مثلا لا يمكــن أن يســندل بصــيغة

مصدره على صيغة الفعل لأن صيغة المصدر المذكورة تكون لأفعال مختلفــة ولئة

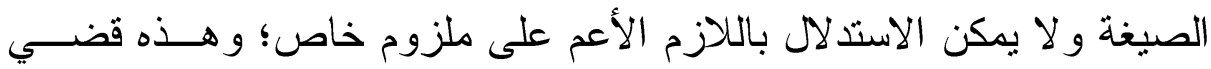

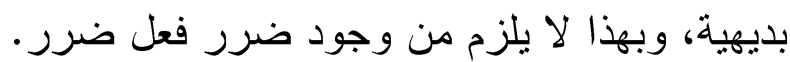
وقد أنكر الباحث استعمال الضرر في غير العمى و الزمانة. وردَّ كلام

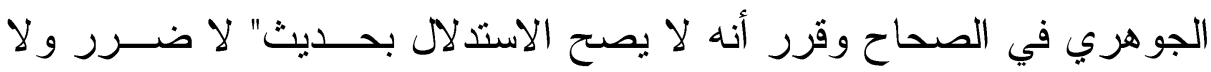

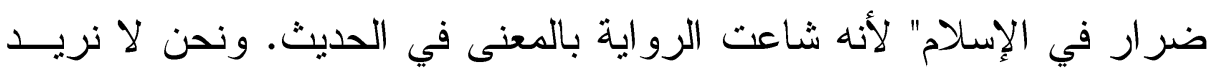

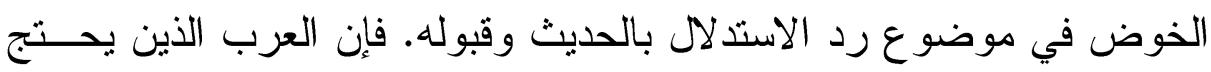
بكلامهم استعملوا الضرر في غير ما قاله الباحث. فال جرير :

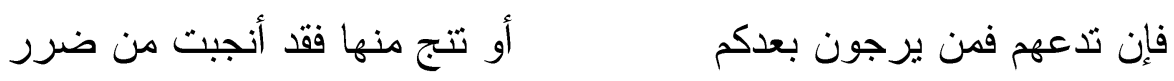

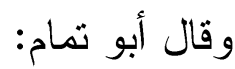

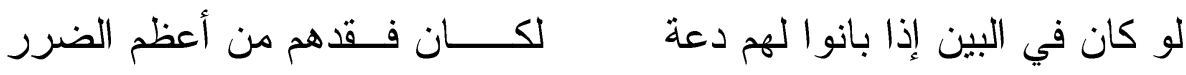




$$
\text { وقد درست اللجنة هذا البحث وو افقت عليه وهي ترى: }
$$

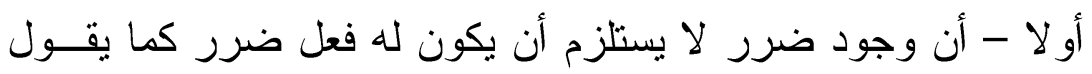

الباحث.

ثانيَّا - أن الضرر يستعمل في غير العاهة و الزمانة. كما جاء في بيتي

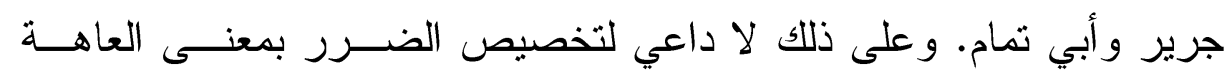

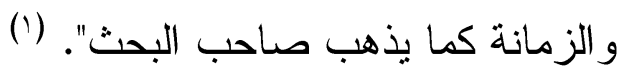

ب - الرد على مقترحات الأستاذ أحمد أمين - رحمـــهـ الله - بشـــأن تيسـير العربية.

في الجلسة السابعة لمؤتمر مجمع اللغة العربية بالقاهرة فــي دورتــهـ

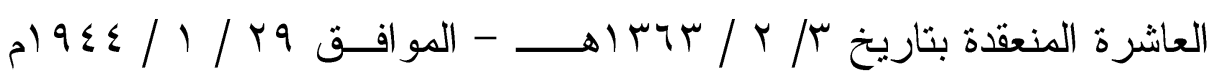

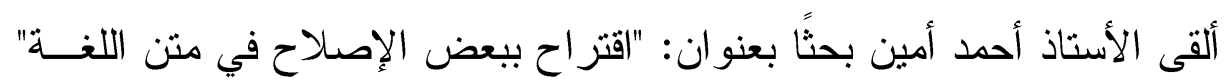

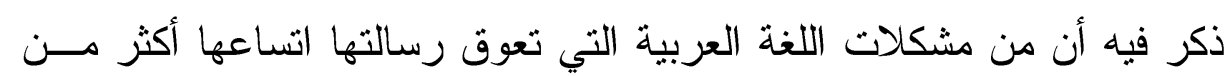

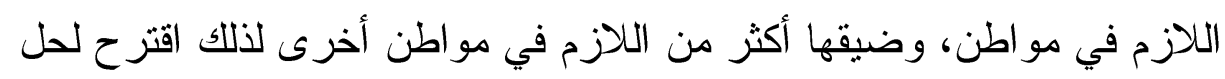
هذا ما يأني:

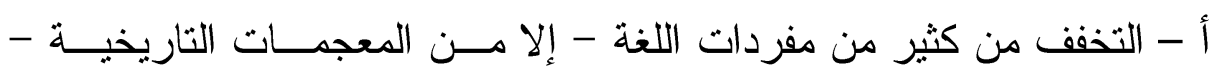

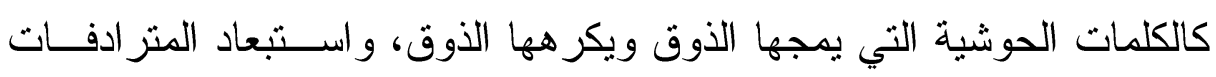
التي لا حاجة لها، وحذف الأضداد والقضاء عليها. ب - فتح باب الاجتهاد في اللغة لتوسيع الضيق عن طريق التعريب و الاشتقاق و القياس.

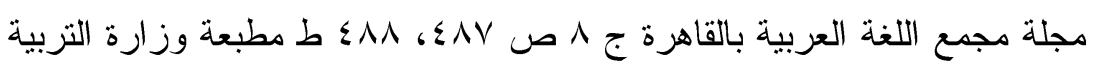
و التعليم 900 (م. 


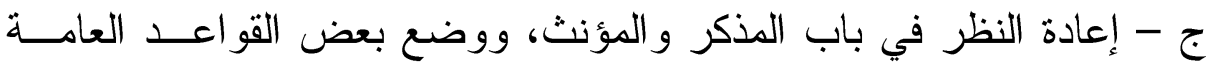

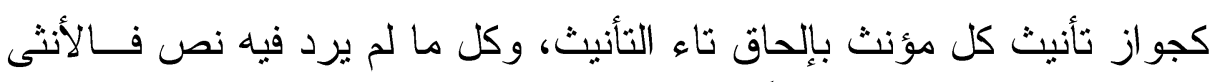

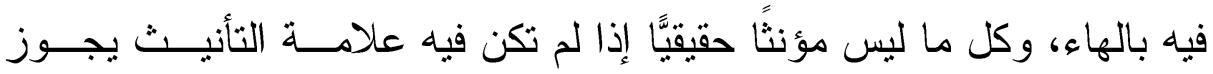

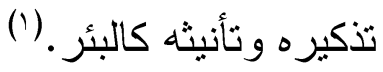

وقد رد الأستاذ الثيخ حُمروش على هذا المقترح في بحث في ســــ

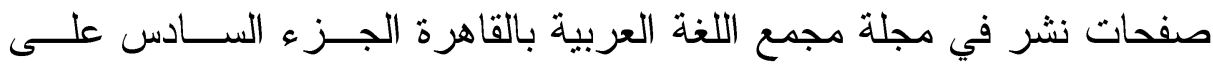

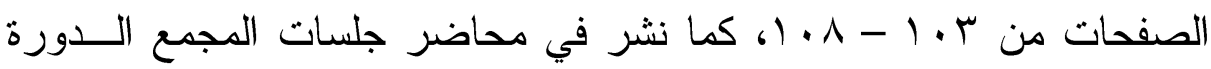
العاشرة، حيث ألقاه الثيخ على المجمعيين في الجلسة الر ابعة عشرة للمــؤتمر

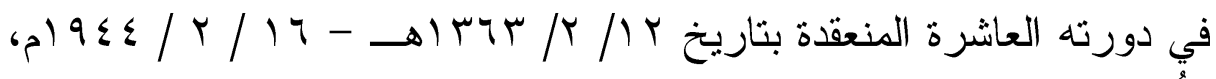

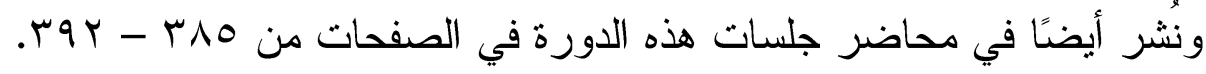

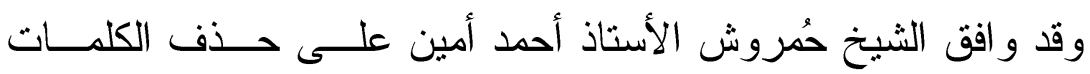

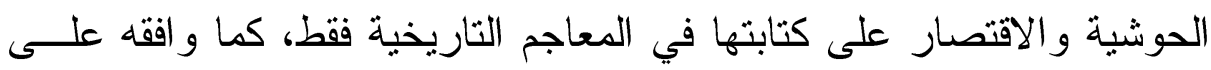
التوسع في اللغة بصوغ مزيدات الأفعال الثلاثية التي لم يسمع لها مزيدات متى

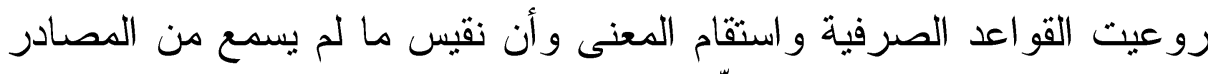

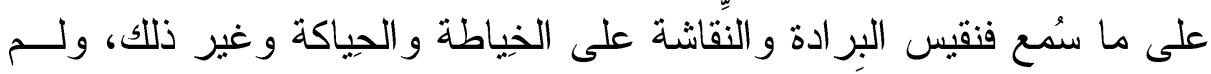

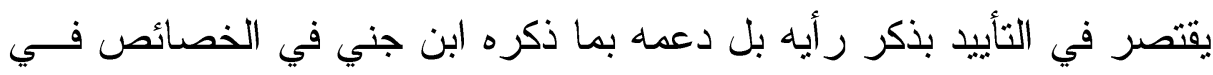

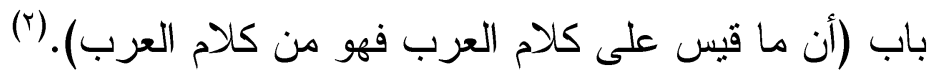

اقتراح ببعض الإصداح في متن اللغة، بحث للأستاذ أحمد أمسـين منثــور فـي محاضر جلسات مجمع اللغة العربية

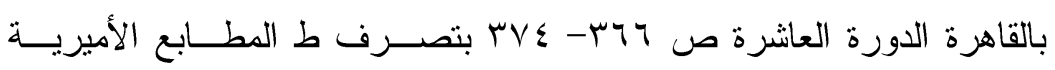
$.019 \mathrm{r}$.

بحث الأستاذ الثيخ إبر اهيم حمروش في الرد على مقترحات الأستاذ أحمد أمين،

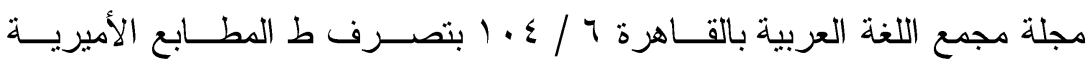


إلا أنه اعترض عليه في بقية ما قدّم ودعم رده بالأدلة الملموسة مسـن

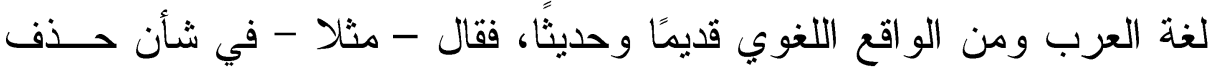

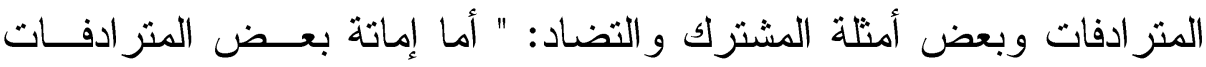

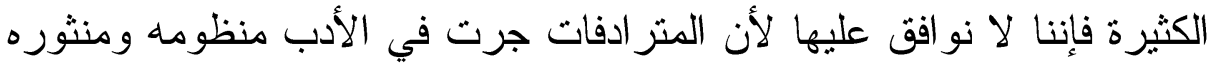

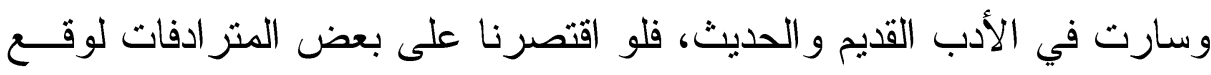

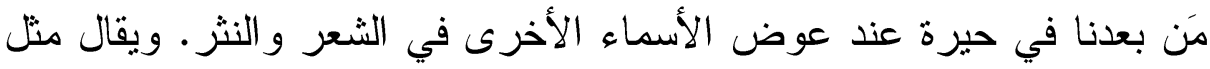
ذلك في المشترك بين الضدين و المشترك بين المتخالفين، ويزيد المشترك بأنه وقع في الكتاب الكريم و السنة الشريفة، وكان وقوع المشترك مثنار خلاف بين

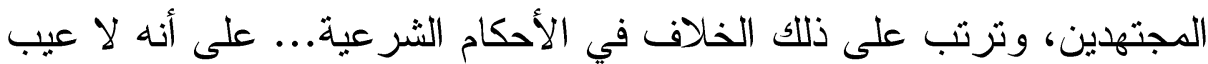

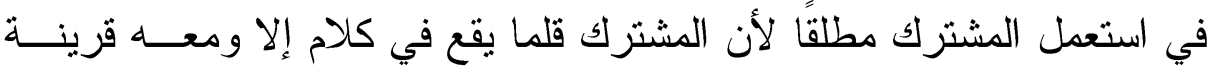

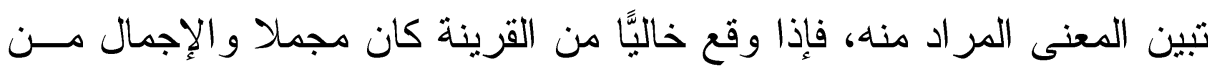

مقاصد البلغاء. (1)

كما اعترض عليه في مسألتي أبو اب الفعل الثناثي، و التذكير والتأنيث.(؟) ج - رسم المصحف

في الجلسة الثالثة من مؤتمر مجمع اللغة العربية بالقاهرة في دورتــهـ

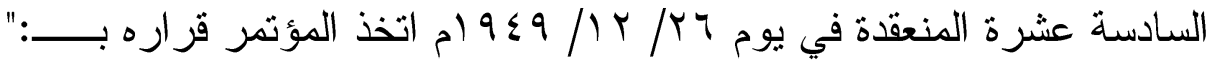
أن يضع الأستاذ الشيخ إبر اهيم حمروش بحثًا في طريقة رسم القرآن، ويترك

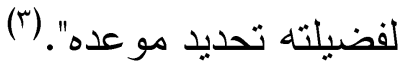

بحث الأستاذ الثيخ إبراهيم حمروش في الرد على مقترحات الأستاذ أحمد أمين،

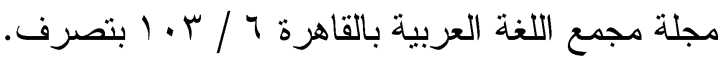

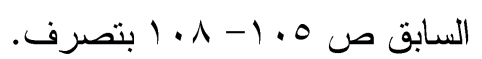

ينظر نص البحث كاملا في: محاضر جلسات مؤتمر مجمع اللغة العربية بالقاهرة

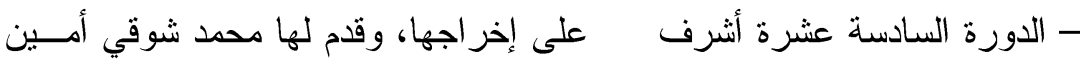

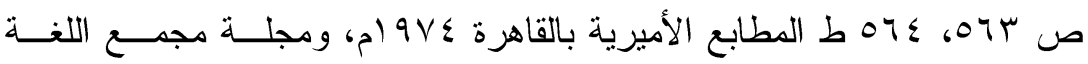
العربية بالقاهرة ج ^ ص ل o ط مطبعة وزارة التربية و التعليم 900 ام. 
وفي الجلسة الثالثة عشر مــن الــدورة ذاتهــا المنعقــدة فــي يـوم

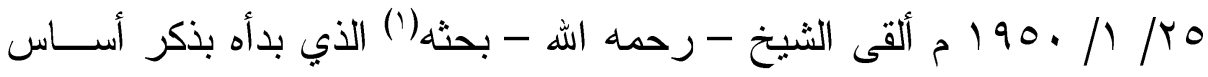
من أسس الخط هو: " الأصل في هذا الخط أن يكون تصويرًا للملفوظ بحروف

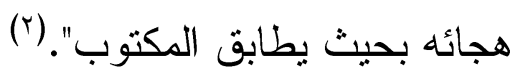
ثم ذكر أن علماء الرسم مزقوا هذا الأصل بكثرة الاســتثناءات فـي

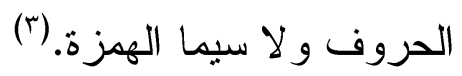

ثم ذكر بعض ظو اهر الرسم المصحفي كزيادة الياء في (نبأ، ووراء)،

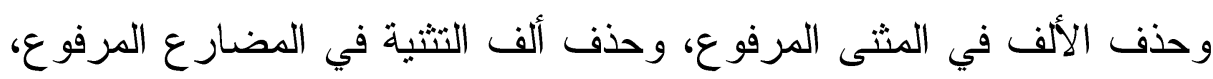

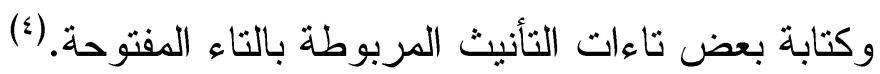

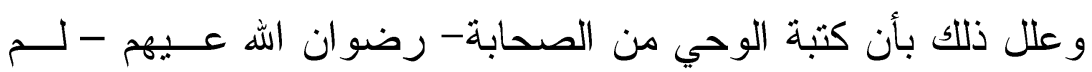
يكونو اعلى حظ واحد من معرفة علم الرسم، فكتب كل وتحد منهم على وفق بن ما بعلم. (0) ثم تعرض لذكر بعض الآراء الفقهية في حكم كتابة القــرآن الكــريم

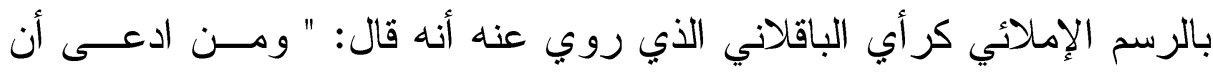
المصحف يكتب برسم مخصوص فهو مطالب بالدليل"، ور أي الإمام مالك الذي

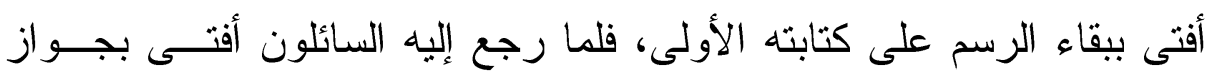

محاضر جلسات مؤتمر مجمع اللغة العربية بالقاهرة - الدورة السادســة عشــرة

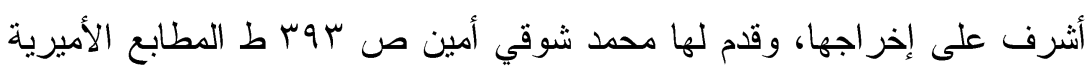

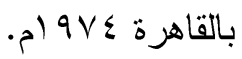

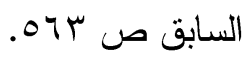

السابق الصفحة ذاتها.

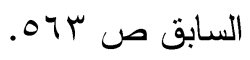

السابق الصفحة نفسها. 
التغيير في كتابة السور لتعليم الأطفال، ور أي العز بن عبد السلام الذي يــرى

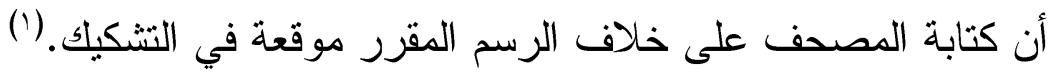

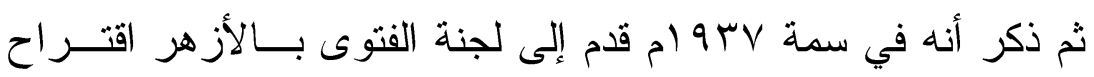

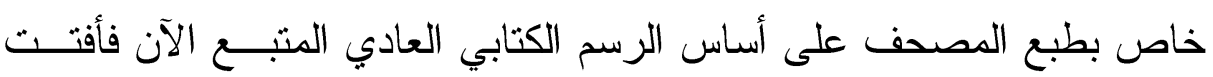
اللجنة بأنها ترى لزوم الوقوف عند المأثور من كتابة المصحف وهجائه، وبنت ذلك على أشياء منها: أن المسلمين درجو ا على كتابة المصحف برسمه الخاص مــن غيـر

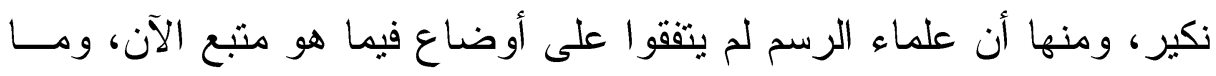

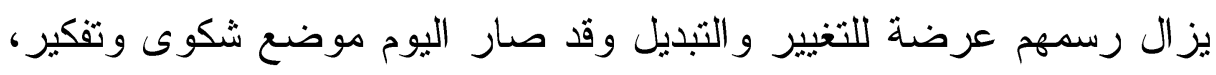
ومنها أن الأئمة في جميع العصور المختلفة درجوا عل التزام الرسم العثماني

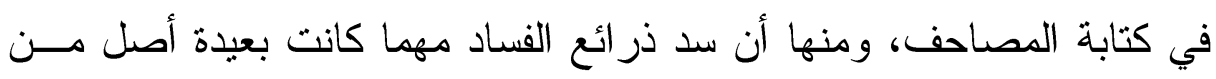
أصول لشريعة الإسلامية التي تبنى الأحكام عليها، وما كان موقف الأئمة من

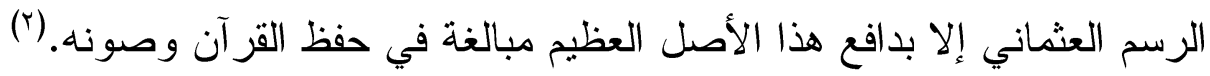

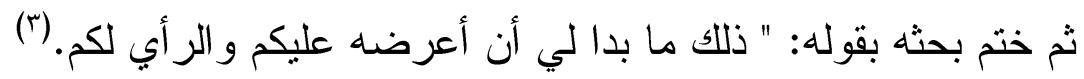

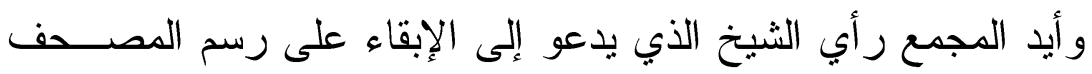

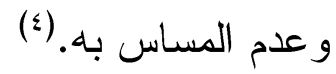

د - طريقة كتابة الألفاظ الأجنبية بحروف عربه

بحث قدمه لمؤتمر مجمع اللغة العربية في دورته الثالثة، ففي الجلسة

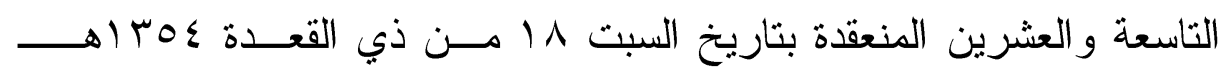

$$
\begin{aligned}
& \text { السابق الصفحة ذاتها. } \\
& \text { السابق ص س 07، ـ } 07 . \\
& \text { السابق ص ع } 70 \\
& \text { السابق ص }
\end{aligned}
$$




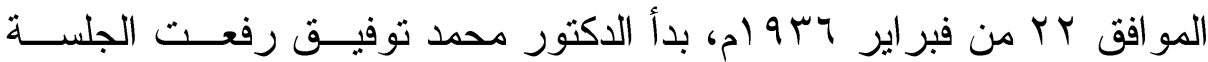
بقوله: " وزع على حضر اتكم بحث في طريقة كتابة الألفاظ الأجنبية للأســاذ الثيخ إبر اهيم حمروش، فنبحث الليلة في هذا الموضوع لنفرغ منه قبل انتهاء

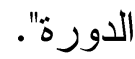

ولم أعثر على نص البحث كاملا، ومما جاء فيه قول الثيخ حُمروش:

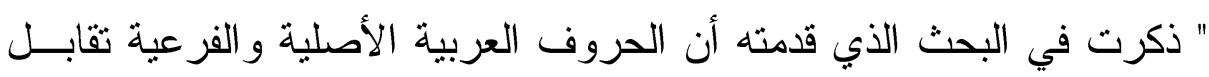
الحروف و الألفاظ في اللغات الأجنبية - كما ينطق بها أهلها - نطق عربــي،

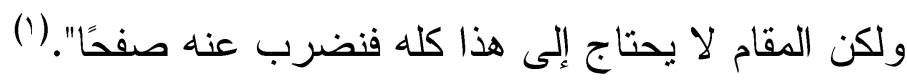

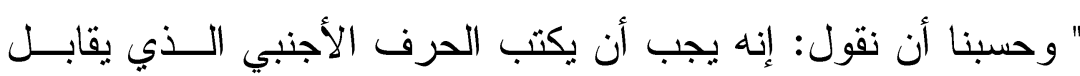

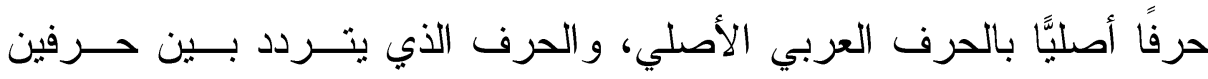
بالحرف الأقرب شيهًا به، وتُضع عليه علامات تدل على حال الحرفي وفئ وكيفية

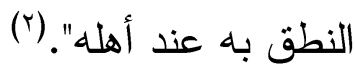

" وقد جرى على ذلك بعض المتقدمين وبعض المتأخرين توصلا لنطق

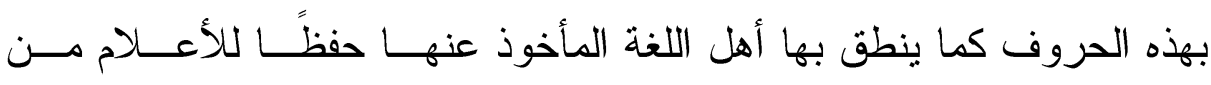

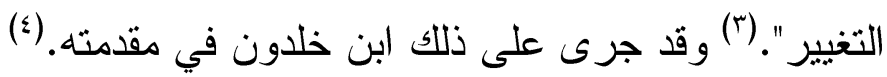

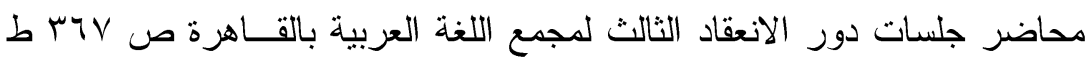

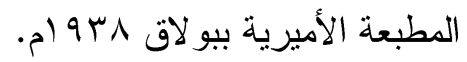

$$
\begin{aligned}
& \text { السابق ص VT"ז. } \\
& \text { السابق ص VTr. }
\end{aligned}
$$

المقدمة عبد الرحمن بن خلدون ص ری ط ط ا المطبعة الأزهرية ـبو ام، وينظر :

$$
\text { تاريخ الكتابة العربية د علي }
$$

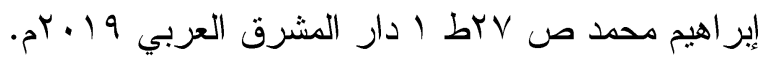




$$
\text { هـ - في الاشتقاق الكبير }
$$

بحث منشور في مجلة مجمع اللغة العربية بالقاهرة الجزء الثاني يقع

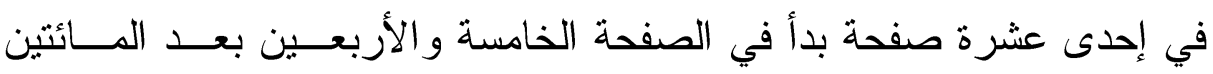
و انتهى في الصفحة الخامسة و الخمسين بعد المائتين. (1) بدأه الثيخ بالحديث عن أنواع النظر في اللغة، وذكر أنه نوعان: نوع بعدين

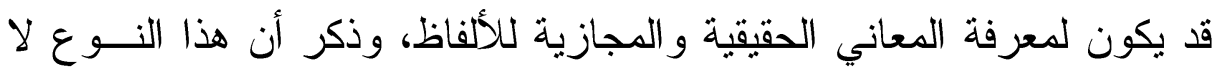
يتجاوز إلى معرفة ما بين المعاني المتعددة من جهات جامعة ومعــان عامـــة مشتركة، كما ذكر أن هذا النوع لا يؤدي إلى استنباط القو اعــد، و اســـتخر اج

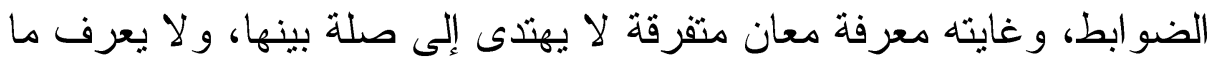
فيه من معان مشترك تجمع متعددها. و النوع الآخر يكون لمعرفة الجهات الجامعة، و المعاني العامــة التـي مئي

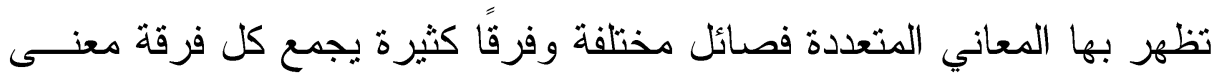
عام ترجع أفر ادها إليه ونتشرك فيه، وبه تمتاز الفرقة من غيرها.(؟) ثم ذكر أن هذا النوع الأخير هو نظر الاشتقاقيين الذي مكنهم مــن رد وده الكلمات التي اشتركت في معنى واحد بعضها إلى بعض بالقاــبـ و الإبـــدال، و أطلاعهم على سر تَوَلّْد اللغة ونمو ها.

كما ذكر قاعدة الاثتقاقيين التي يعرفون بها اتصال معـاني الكلمـات و هي: " أن كل كلمتين اتفقا في الفاء و العين كان بين معنيهما اتصال".

في الاشتقاق الكبير، بحث للأستاذ الشيخ إبراهيم حمروش، مجلة مجمــع اللغـــة

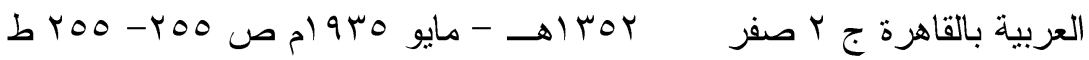

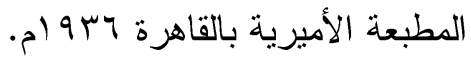

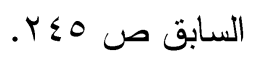


وذكر أن هذه القاعدة لم تكن مبتناة على أن الفاء أو العين مقطع حُكي به بعض الأصوات الطبيعية للأجسام والحيوان، كهبوب الريح، وخرير الماء،

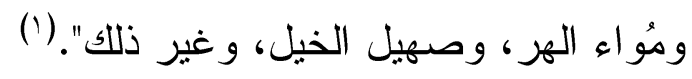
و استدل على ذلك بأنهم أطلقو القاعدة ولم يقيدو ها بشيء، و وأنه لـــــ في كلامهم إثارة إلى حكاية الأصوات، ثم ذكر مثالا واحدًا مما ذكره القدماء هو قولهم إن الهمزة و الباء مدلولهما النفور و البعد و الانفصـال بــين الثـــيئين.

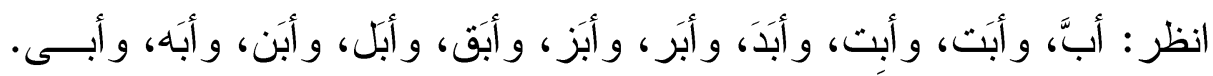

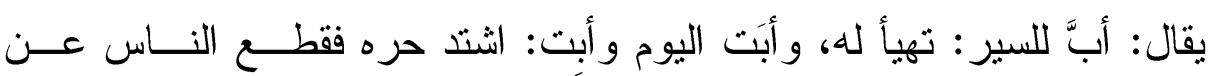

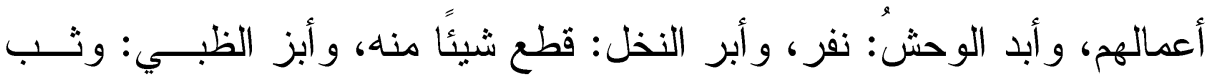
و انطلق، وأبق العبد: نفر عن مولاه. (r) ثم علق على هذا المثال بقوله: " لا يخفى أن بعض الأبنية المتقدمة قد في

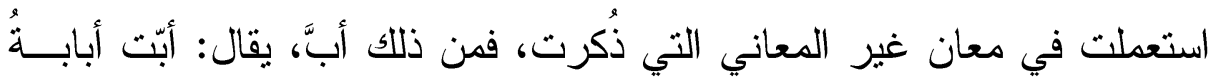

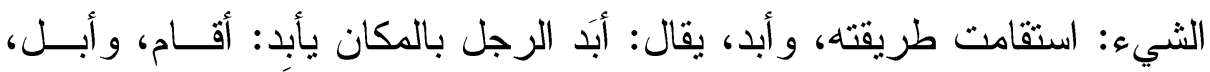

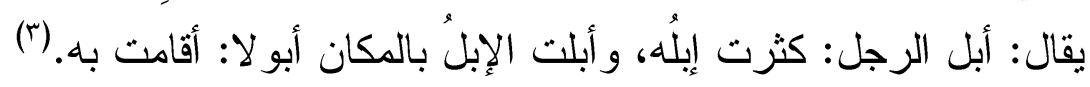

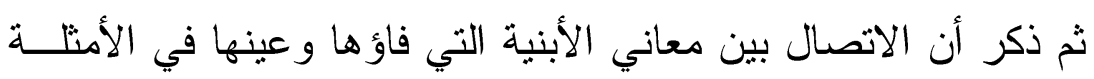

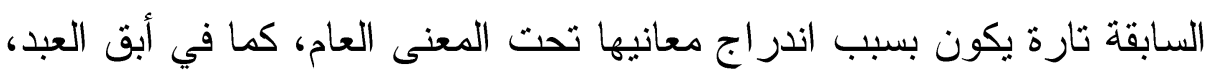

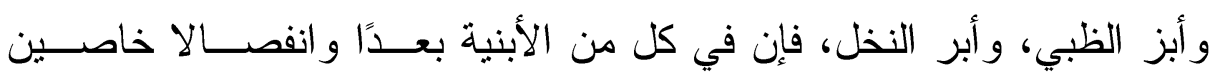
يندرجان تحت البعد و الانفصال العامين.

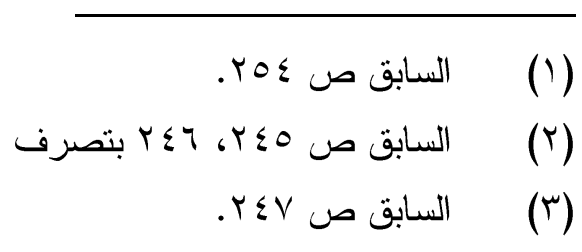


وتارة يكون الاتصال بين المعاني في هذه الأبنية بسبب تحقق المعنى

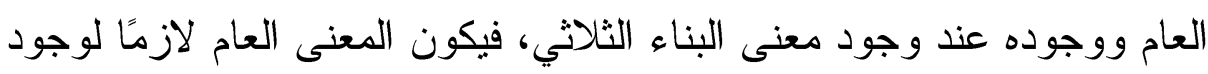

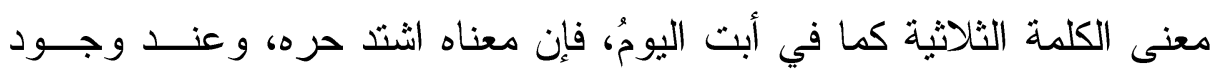

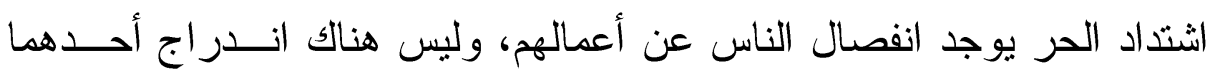

تحت الآخر، فإن اشتداد الحر شيء وفصل الناس عن أعمالهم شيء آخر. (')

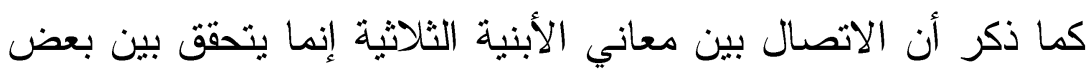

معاني الأبنية المذكورة لا كلها. (r)

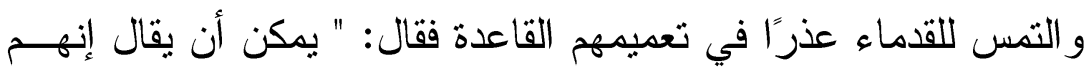

ينظرون في قاعدته إلى المعاني الأصلية دون المعاني التي اســتعملت فيهــا

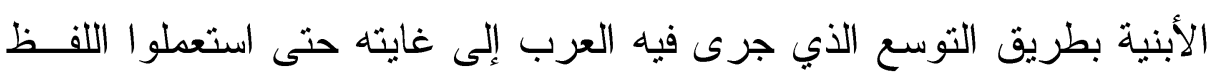

في ضد معناه".(r)

ويرى أن هذه لقاعدة عرض لها التخلف في بعض المواد، إذ تحقــق

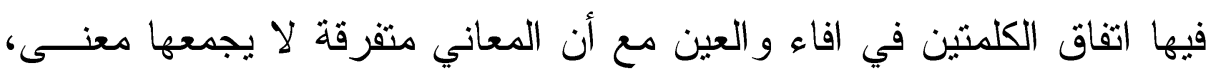
ولا يوجد فيها جهة جامعة، ومن المواد ما تجري هذه القاعدة في أكثر أبنيتها

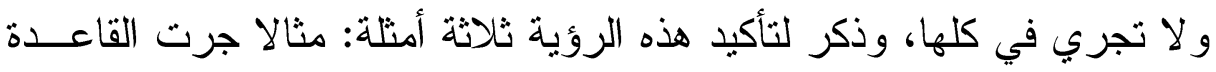
في جميع أبنيته هو اجتماع الراء و الخاء ودلالتهما على اللين و السهولة، ومثالا جرت القاعدة في أكثر أبنيته ولم تجر في الجميع هو اجتماع الســين و الــلام

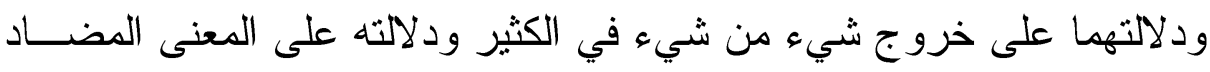

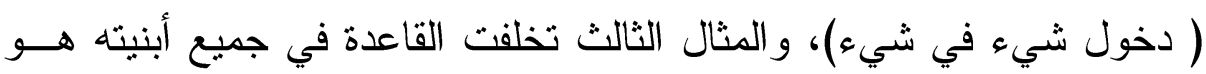

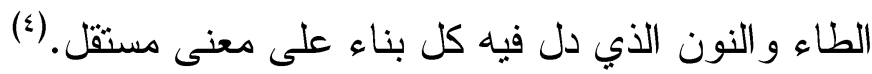

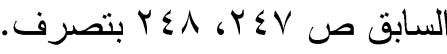

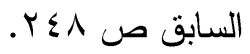

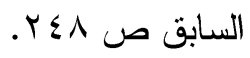

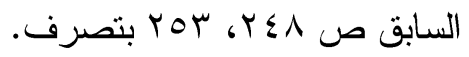


ثم تعرض لسبب أخر يجمع بين المعاني في الأبنية الثلاثية التي تثفق في الفاء و العين من وجهة نظر القائلين بنشأة اللغة عن طريق التقليد و المحاكاة

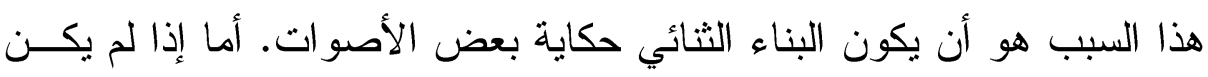

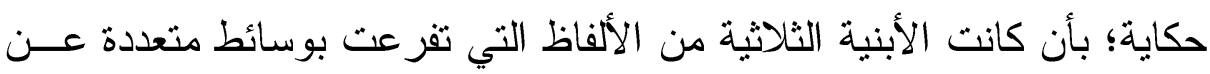

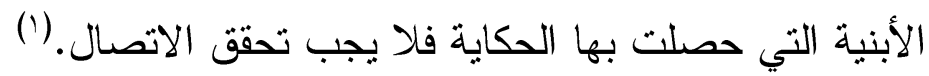

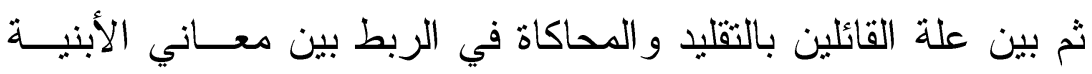
الثثلاثية المتفقة الفاء والعين إذا كان البناء الثنائي حكاية بعض الأصو ات ومثلَّل لذلك فقال: " وذلك لأنهم يقولون: إن الأصوات الطبيعية هجاء واحد - إما ساكن

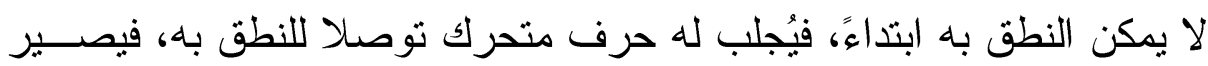

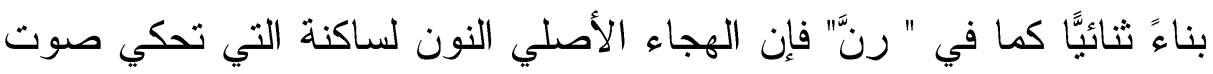

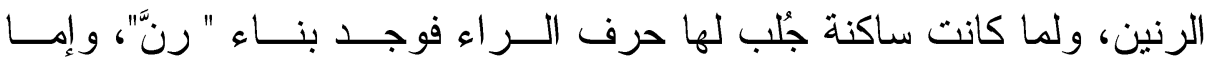
متحركة بحركة ممتدة يتولد عنها حرف لين، إما واو أو ألف او ياء كما فـي

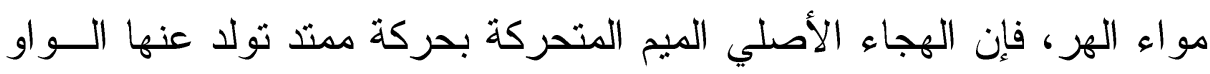

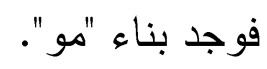

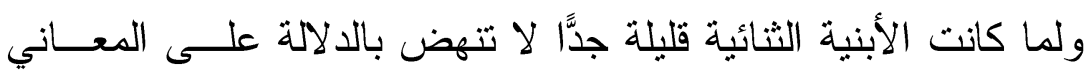
الكثيرة التي تتطلبها حياة الإنسان الاجتماعية قضت الضرورة بزيادة الحرف الثالث فزيد، لكن بملاحظة وجود معنى البناء الثنائي في جميع الأبنية الثالثية،

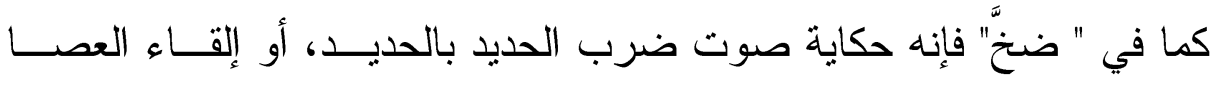

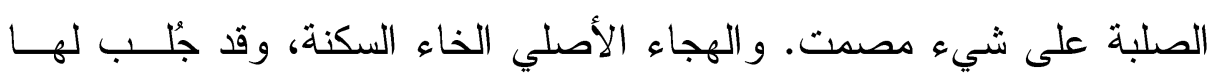
حرف الصاد المتحرك توصلا للنطق بهاء 
وقد جاء من الثلاثي صنخ، وصخب، وصخد ومعنى البناء الثتـائي -

وهو الصوت- متحقق في جميع الأبنية الثلاثية المذكورة. (')

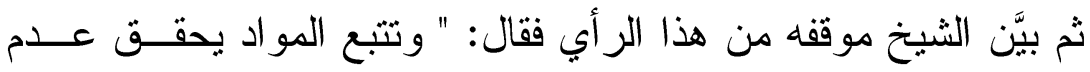

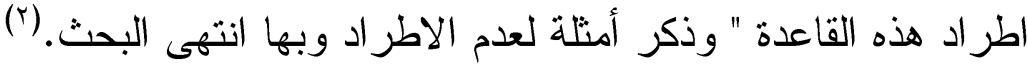
و - النحت

في الدورة الثالثة عشرة لمؤتمر المجمع نم تشكيل لجنة لبحث موضوع

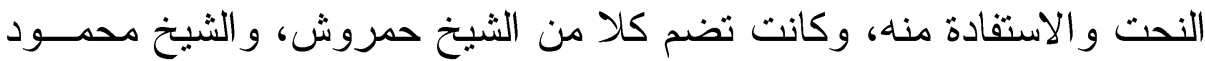

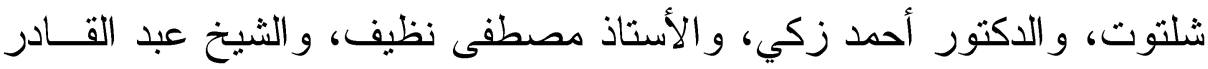

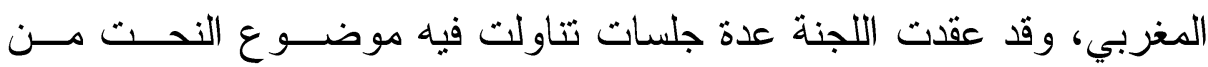
مختلف أطر افه، ور اجعت لأقو ال المتقدمين فيه، ثم أسندت إلى فضيلة فيلة الثـــيخ إبر اهيم حمروش وضع البحث المطلوب فوضعه فضيلته. (ץ)

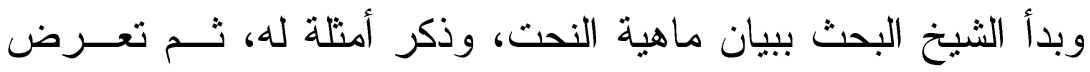
لضوابطه عند العلماء، ثم تعرض لمسألة قياسية النحت وسماعيته و انتهى إلى لى لئه

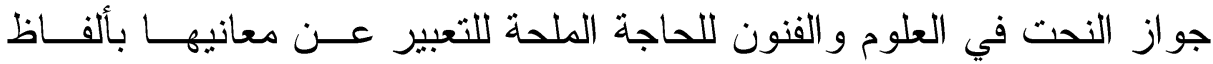

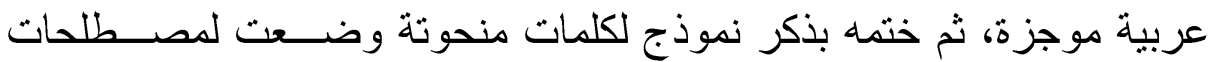

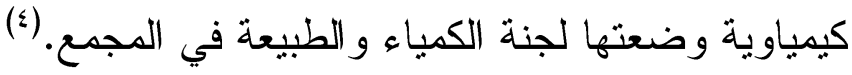

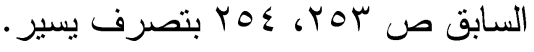

$$
\begin{aligned}
& \text { السابق ص \& YOr، ro0. }
\end{aligned}
$$

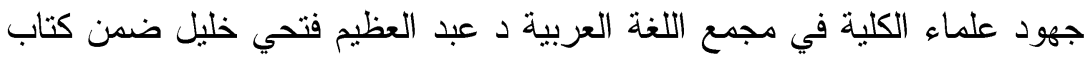
الندوة العلمية الأولى بمناسبة اليوم العالمي للاحتفال باللغة العربية بعنــــان

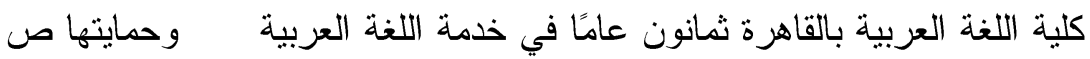

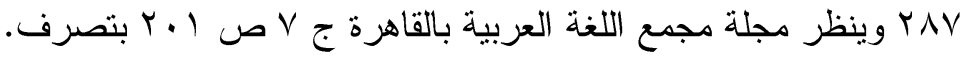

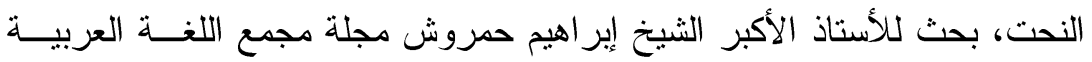

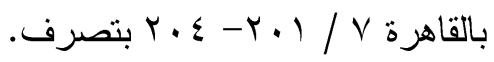


- V

عقب اجتياز الثيخ لاختبار العالمية عين مدرسًا في الأزهر الثــريف

في الحادي و العشرين من نوفمبر عام 7 ـ 9 (م. (')

ثم انتقل للعمل في القضاء الشرعي في سا من شـــر يونيــو ســـنة

1.9 ا ولم يلبث فيه إلا قرابة مائة يوم حيث تم اختياره مدرسًا في مدرســة

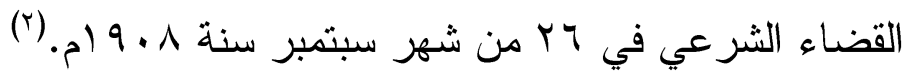

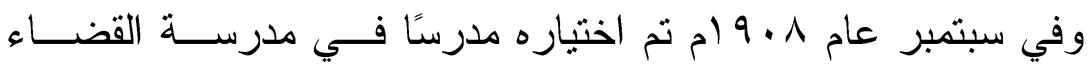

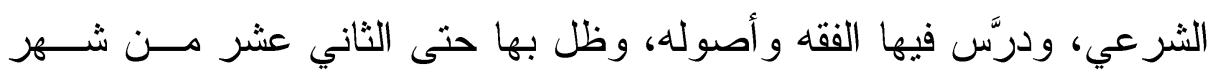

$$
\text { يونيو عام } 917 \text { ام. }
$$

وبعدها عُين قاضيَّا في المحاكم الثرعية وظل يرقى في مناصبها حتى أنى

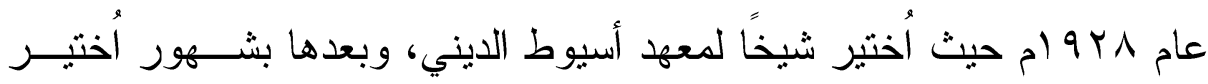
شيخًا لمعهد الزقازيق الأزهري.

وفي الثالث عشر من شهر يونية عام اسبو ام تم اختياره شيخًا لكليـــة

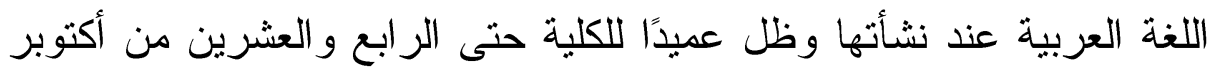

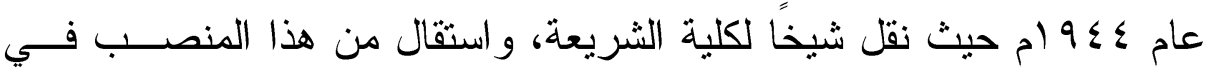

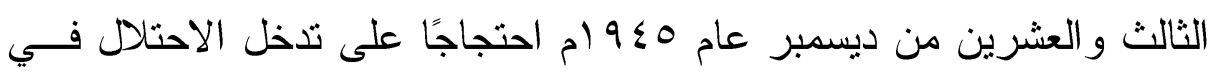
شؤون الأزهر الشريف.

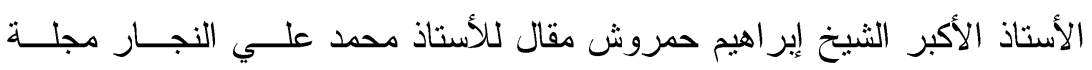

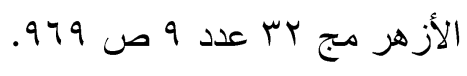

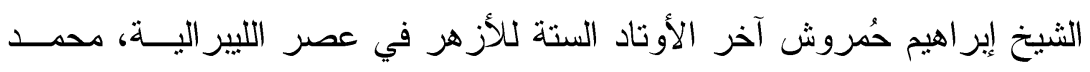
الجو ادي مقال للكاتب على صفحته: www.gwady.net 
في سنة .90 190 تم تعيينه رئيس للجنة الفتوى بالأزهر ، وفي الثلاثـين

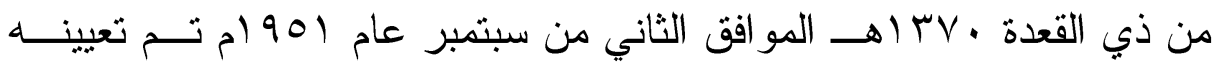
شيخًا للأزهر الشريف، وتم إعفاؤه من هذا المنصب بعد أن نم فيه ستة أشهر

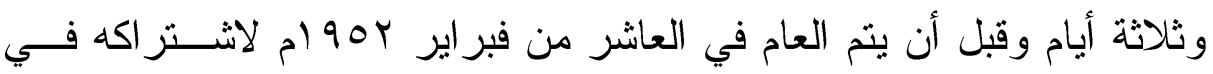
الحركة الشعبية التي نادت بالحرية لمصر من نير الاستعمار، ولمقالاته التـي ماتي دعت لمناهضة الاستعمار الغاشم. (')

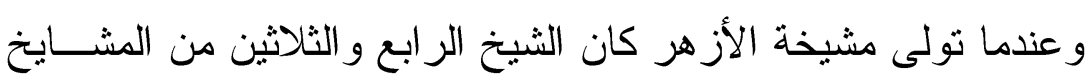

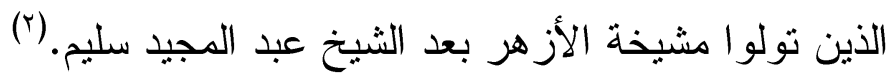

^ - من مو اقفه الحماسية في الحث على الجهاد و الذود عن الوطن في كلمته للأمة بمناسبة ذكرى مولا الرسول - صلى الله عليه وسلم -

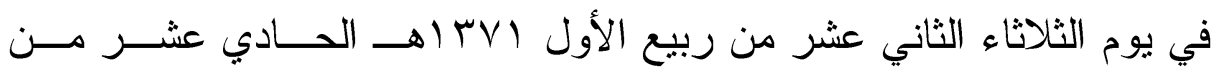
ديسمبر 901 ام قال داعيَّا إلى الجهاد ومرغبًا فيه: " ووجه هذا الدين الأمســة إلى ما يعلي قدر ها، ويرفع شأنها بين الأمم. طالب الأمة بإعداد ما تقدر عليه من قوة، وباتخاذ ما تستطيعه من عتاد، وطالبها بجهاد الأعداء الذين يحاولون ئن لها كيدًا، ويريدون بها شرَّا ونوَّه بفضل الجهاد و عظيم ثو ابه، وجزيل ما يلقاه

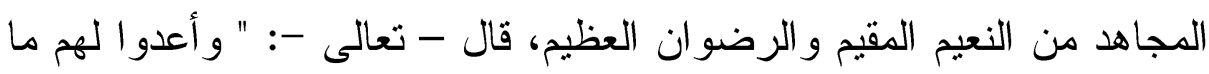
استطعتم من قوة ومن رباط الخيل ترهبون به عدو الله وعـدوكم". وقــــال -

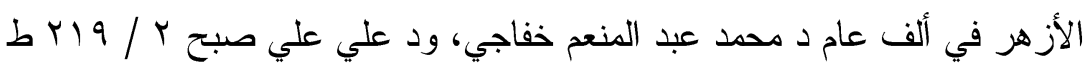
r المكتبة الأزهرية للتراث

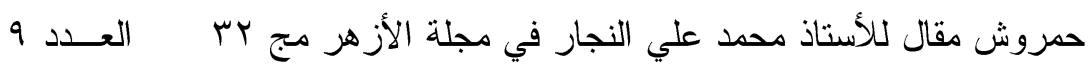

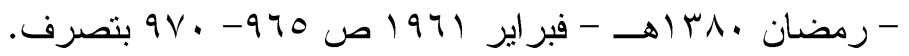

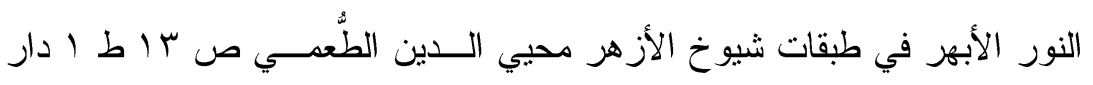

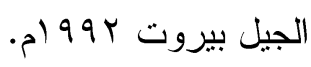


تعالى -: " يأيها الذين آنوا هل أدلكم على تجارة تتجيكم من عذاب أليم تؤمنون بالله ورسوله وتجاهدون في سبيل الله بأمو الكم و أنفسكم". وقال- عليه السلام-: " لغدوة في سبيل الله أو روحة خير مما تطلع عليه الشمس وتغرب". إلى غير وله وله

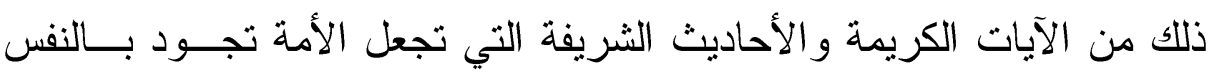
وتسخو بالمال ابتغاء العزة و الكر امة و الدرجة الســامية و المرتبــة العظيمــة،

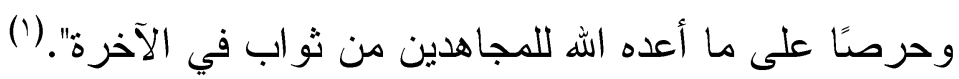

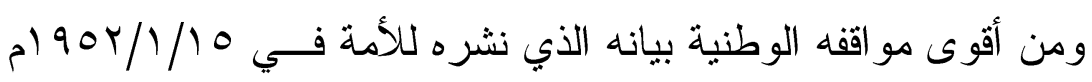

عقب اعتداء الإنجليز على الثرطة الذي قال فيه: " أيها المصريون، أتوجــهـ

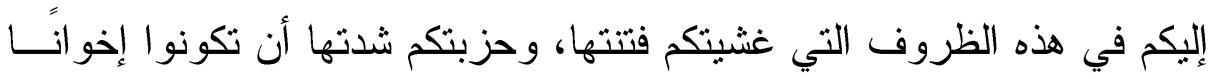

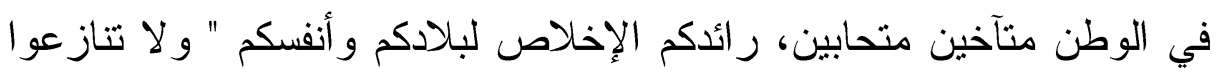

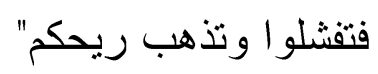

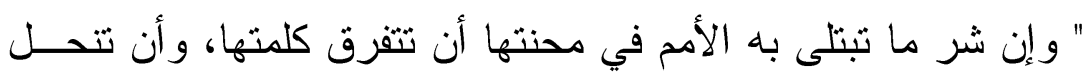
وحدتها، وتثقطع أو اصر المودة بين جماعاتها، فيشق العدو الطريق إليها، وينفذ بسهامه إلى صدور أبنائها". و هذه مصر، بلادكم العزيزة ووطنكم المحبوب تتاديكم جميعًّـا شـيـًا

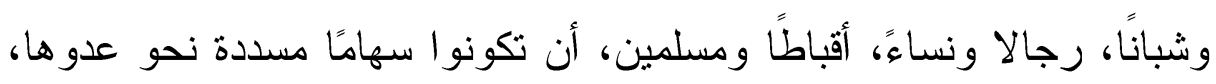

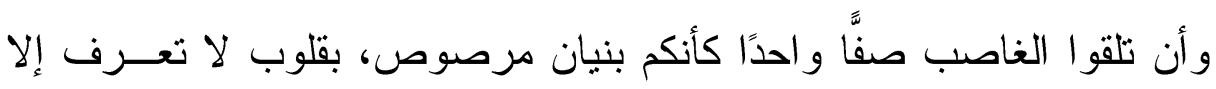
الوطن و الدفاع عن حوزته". (r)

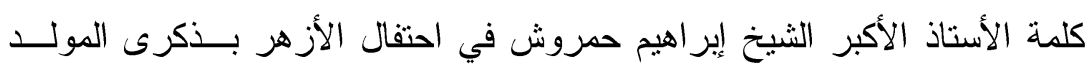

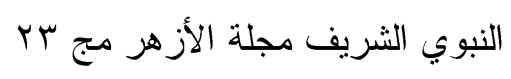

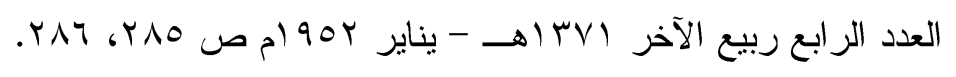

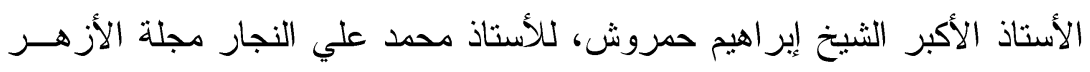


9

لبى الثيخ نداء ربه بعد حياة حافلة بالعطاء العلمي و الكفاح الــوطني،

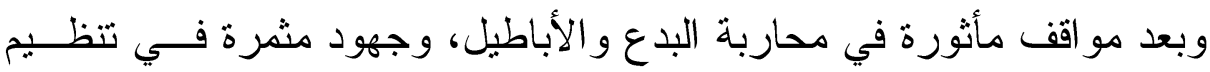

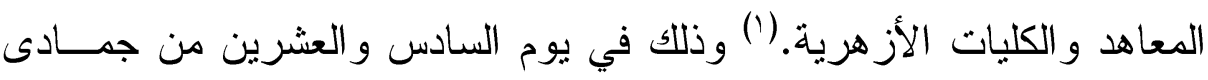

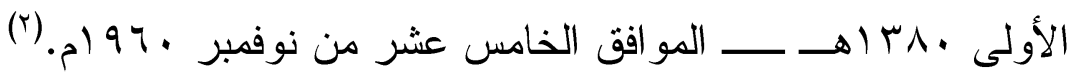

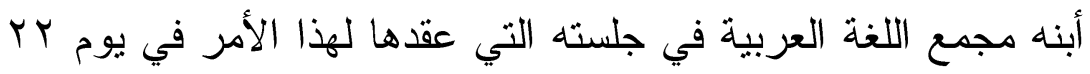

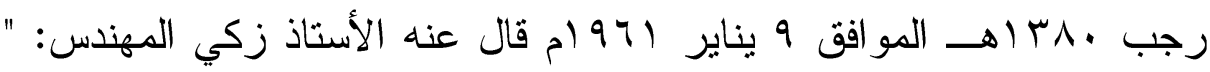

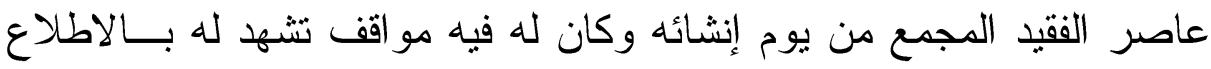

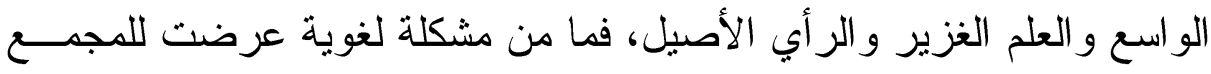

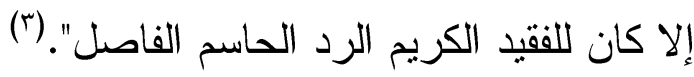

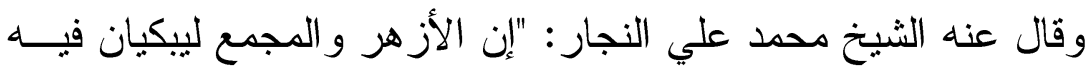

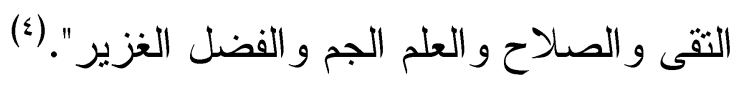

وقال عنه خلفه في المجمع الدكتور محمود توفيق حفناوي: "كــان -

رحمه الله - متفرغًا للغة العربية يعشق بحوثها ويتتبع غو امض أصولها".(0)

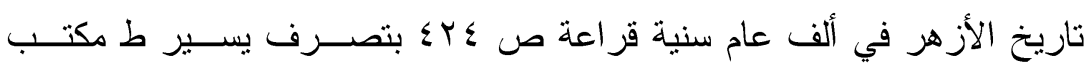

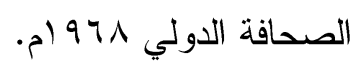

الأستاذ الأكبر الثيخ إبراهيم حمروش، للأستاذ محمد علي النجار مجلة الأزهـر

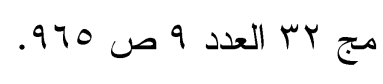

تأبين المرحوم الثيخ إبراهيم حمروش - كلمة الأستاذ زكي المهندس مجلة مجمع

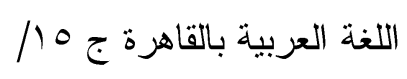

.

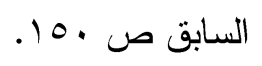

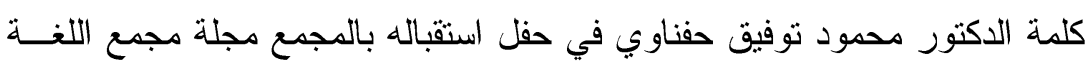

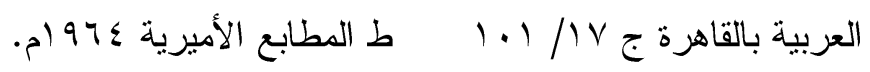


وقال عنه أيضنًا: " وتولى الثيخ إبر اهيم حمــروش - رحمـــهـ الله -

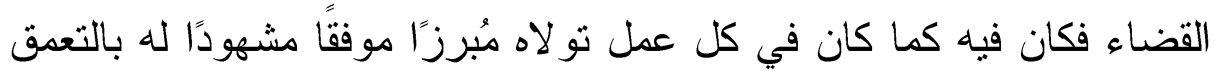
وصدق الحكم".(') نسأل اله العظيم رب العرش العظيم أن يثقل موازينه بأعمالــهـ التــي العي

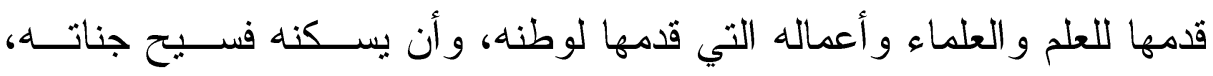

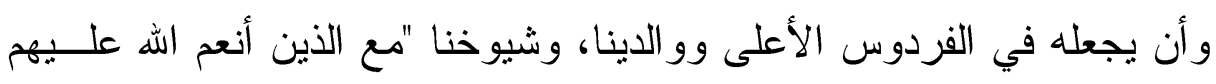
من النبيين و الصديقين و الثهداء و الصالحين وحسُن أولئك رفيقًا".

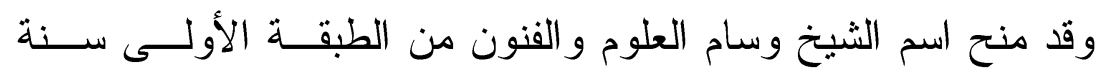

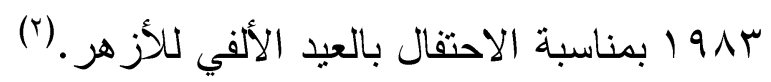

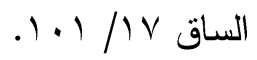

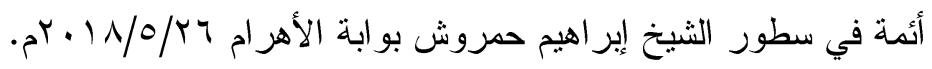

$$
\begin{aligned}
& -117 \leqslant-
\end{aligned}
$$




\section{هصادر البحث وهراجعه}

أئمة في سطور الثيخ إبر اهيم حمروش بوابة جريدة الأهرام المصرية

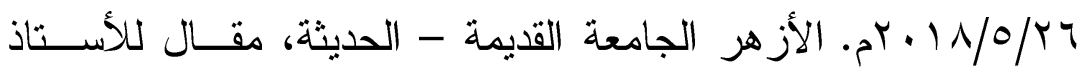

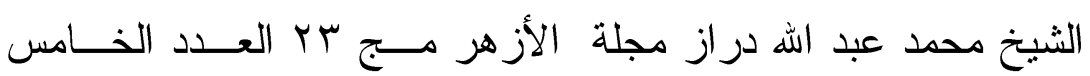

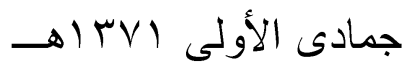
الأزهر في ألف عام د محمد عبد المنعم خفاجي، ود علي علي صبح

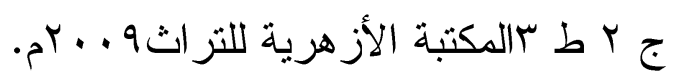
الأستاذ الأكبر الشيخ إبر اهيم حمروش، مقال للأستاذ محمد علي النجار

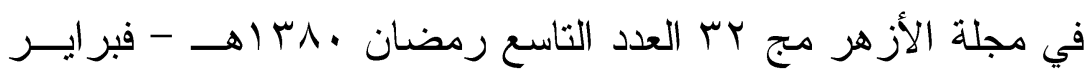
. 1971

أعمال مجمع اللغة العربية بالقاهرة، د محمد رشاد الحمـز اوي ط ا دار الغرب الإسلامي بيروت 911 ام.

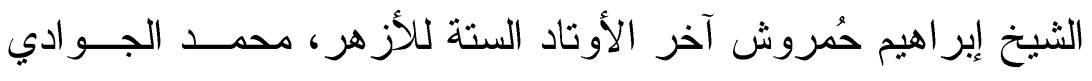
مقال على موقع .www.gwady.net

بحث في رسم المصحف للأستاذ الأكبر الثـــيخ إبــر اهيم حمـروش،

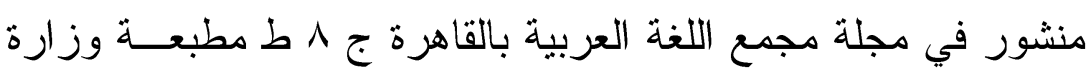
التربية و التعليم 900 ام. البصائر النَّصيرية في علم المنطق للقاضي زين الدين عمر بن سهلان

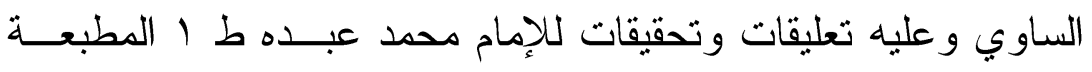

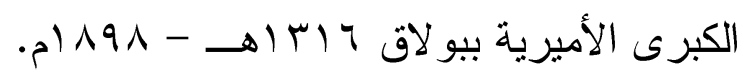


تأبين المرحوم الثيخ إير اهيم حمروش، مجلة مجمع اللغـــة العربيــة

$$
\text { بالقاهرة ج } 10 .
$$

تاريخ الأزهر في ألف عام، سنية قر اعة ط مكتب الصــــافة الــدولي

$$
\text { . } 971
$$

تاريخ الكتابة العربية، علي إبر اهيم محمد ط ا دار المشرق العربـي

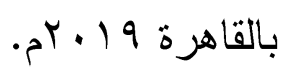

التضمين ونيابة بعض عن بعض، بحث للأستاذ الأكبر الشيخ إبر اهيم حمروش، بحث منشور في محاضر جلسات مجمــع اللغـــة العربيــة

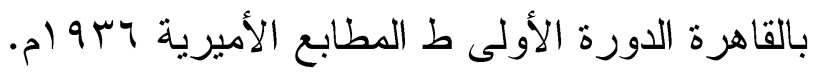

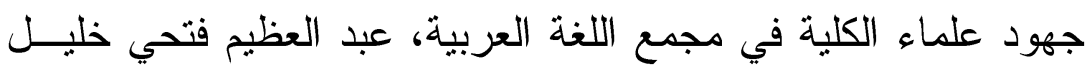
ضمن كتاب "كلية اللغة العربية بالقاهرة ثمانون عامًا في خدمة اللغــة

$$
\text { العربية وحمايتها" الصادر عن }
$$

الندوة العلمية الأولى بمناسبة اليوم العالمي للاحتفال باللغـــة العربيـــة

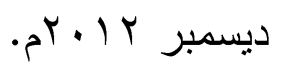

سلسلة أعلام الأزهر في القرنين الرابــع عشـر و الخــامس عشــر

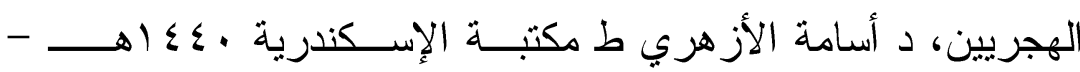
$\cdot p^{r} \cdot 19$

فرق لغوي مسكوت عنه للشيخ محمد الطاهر بن عاشور ورد الثــيخ

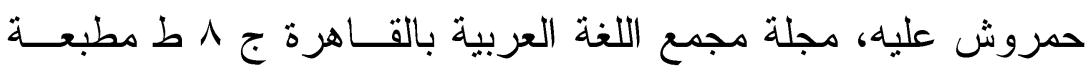
وزارة التربية و التعليم 900 (م. في الاشتقاق الكبير، بحث للأستاذ الشيخ إبر اهيم حمروش منشور في

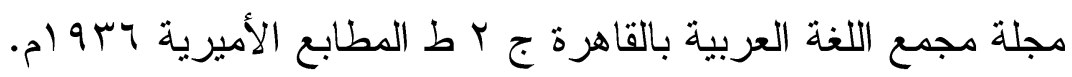


كلمة الأستاذ الأكبر الشيخ إبراهيم حمروش في احتفال الأزهر بذكرى المولد النبوي الشريف مجلة الأزهر مج سب العدد الرابع ربيع الآخر

$$
\text { . } 90 \text { - يناير }
$$

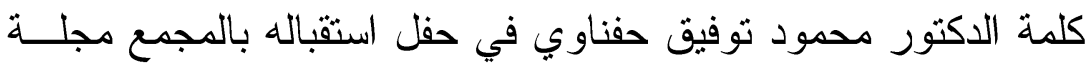

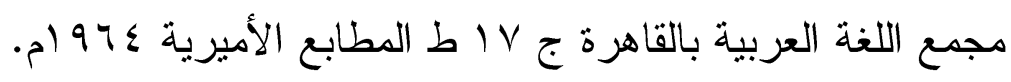

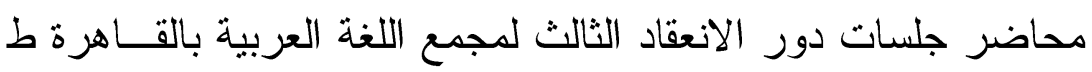
$\ddot{a}$

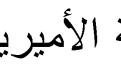

$$
\text { بولاق مباو ام. }
$$

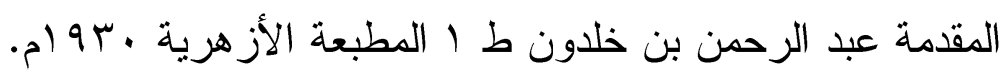

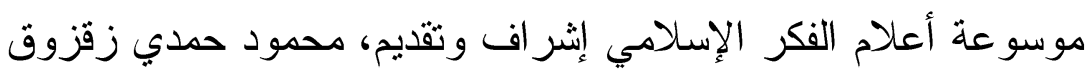

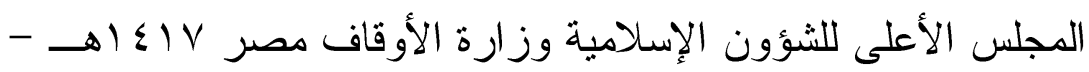
$\cdot r+\cdot V$

النحت، للأستاذ الشيخ بر اهيم حمروش مجلة مجمــع اللغـــة العربيــة بالقاهرة الجزء السابع، ط مطبعة وزارة المعارف العمومية سمو ام.

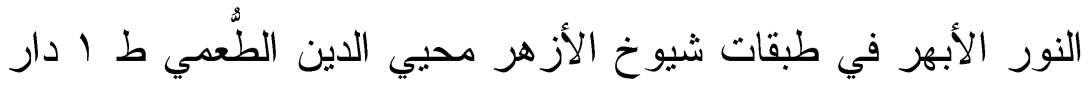

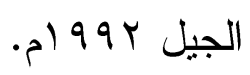
يوميات العقاد الجزء الر ابع ط مطابع دار الشعب د ت. 
